\title{
O que pensa quem "bate à porta" de uma Casa que só "apanha"? Percepções e orientações dos visitantes sobre o Congresso Nacional
}

\begin{tabular}{c}
\hline \hline Ana Lúcia Henrique \\
Doutoranda em Sociologia \\
Universidade Federal de Goiás \\
\hline \hline
\end{tabular}

\begin{abstract}
Resumo: Há uma crise mundial de credibilidade do Poder Legislativo. Para a literatura culturalista, ela decorre principalmente da reprovação ao desempenho dos representantes e da ausência de "responsividade" das instituições às demandas de cidadãos cada vez mais escolarizados, exigentes e críticos. Nesta perspectiva, o conhecimento do papel institucional é determinante para a cidadania ativa e para a qualidade do regime e as ações de educomunicação podem aumentar o conhecimento, a familiaridade e a confiabilidade das instituições. $O$ artigo analisa as orientações dos visitantes ao Congresso Nacional para avaliar o impacto de programas de visitação na percepção institucional e, por esta via, na qualidade do regime. As conclusões abrem novas perspectivas sobre o papel do Legislativo como educador para a cidadania pela análise das percep̧̧̃es sobre o desempenho dos parlamentares, a adesão à democracia e a confiança política, em amostras antes e depois da visita.
\end{abstract}

Palavras-chaves: confiança política; cidadania; turismo cívico; qualidade da democracia

Abstract: Confidence in legislatures is at low ebb. For literature, it derives from Congressional job disapproval due to lack of responsiveness to the demands of citizens more educated, thus, more critical. In this perspective, knowledge of the institution's role is important to active citizenship and actions of edu-communication may be relevant to increase familiarity. The article examines the perceptions and orientations among visitors to the Brazilian National Congress to assess familiarization visits as tools for improving legislatures' reputation, therefore enhancing the quality of democracy. It reveals new perspectives to the legislatures' role on civic education through the analyses of visitor' orientations on specific congressmen's performance assessment and diffuse political support.

Keywords: political trust; citizenship; civic tourism; quality of democracy 
HENRIQUE, A. L. O que pensa quem "bate à porta" de uma Casa que só "apanha"?...

\section{Introdução ${ }^{1}$}

Lijphart (2003, p. 70) estabelece um mínimo de 20 anos ininterruptos de observação dos oito requisitos propostos por Dahl (1997, p. 27) para que um sistema político seja considerado democrático. Assim, vencido o período de "estágio probatório" do regime iniciado com a eleição direta do primeiro presidente civil, em 1989, o Brasil parece ter abandonado o rol das democracias "instáveis" para ser hoje considerado não só um país democrático pela Freedom $\mathrm{House}^{2}$, como também uma das quatro maiores democracias do mundo em número de eleitores. Certamente, por este fato, associado ao verdadeiro "tsunami democrático" que vem "assolando" o mundo desde o fim do século XX (HUNTINGTON, 1991), a estabilidade da democracia brasileira deixou de ser tema central do debate da Ciência Política, que hoje se debruça sobre a legitimidade e a qualidade do regime (DIAMOND; MORLINO, 2005). A questão é particularmente importante em novas democracias (LINZ; STEPAN, 1996; MERKEL, 2004), como o Brasil, onde o chamado déficit democrático pode incidir em prejuízo para a participação cidadã, a consolidação dos direitos, o progresso (HARRISON; HUNTINGTON, 2000), a redução de desigualdades e a governança democrática (NORRIS, 2011; 2012).

Paradoxalmente, neste mesmo período, sete entre dez brasileiros, em média, desconfiam do Congresso Nacional, instituição central da democracia (HENRIQUE, 2009). A queda dos índices de confiança nas instituições legislativas não é prerrogativa brasileira. É fenômeno que atinge poliarquias modelares (DALTON, 2004) e novas democracias (MoISÉs, 2010). O ceticismo em relação às instituições democráticas centrais, no entanto, é visto com preocupação pela literatura culturalista, que tem como obra seminal a Cultura Cívica de Almond e Verba (1963), por suas consequências para a formação do capital social - principal elo entre a confiança e a qualidade da democracia (PUTNAM, 1993; 1995; 2000), e para a participação cidadã, fundamental para um regime que se pretende inclusivo e responsivo (DAHL, 1997; DIAMOND; MORLINO, 2005). Segundo Powell (2005):

"A responsividade ocorre quando o processo democrático induz o governo a formar e implementar políticas públicas que os cidadãos desejam. Uma democracia é considerada de alta qualidade quando o processo cumpre este papel consistentemente" 3 (POWELL, 2005, p. 62).

Nesta perspectiva, a confiança social e a confiança em instituições democráticas aparecem entre os valores centrais para a qualidade da democracia, enquanto parte de uma cultura cívica, ou seja, "uma distribuição particular de padrões de orientação com relação a objetos políticos entre os membros

\footnotetext{
${ }^{1}$ A autora é bolsista da FAPEG (Fundação de Amparo à Pesquisa do Estado de Goiás), professora e pesquisadora do Centro de Formação, Treinamento e Aperfeiçoamento da Câmara dos Deputados (CEFOR). Lattes: http://lattes.cnpq.br/8090637859440030. Este artigo deriva de trabalho do Grupo de Pesquisa (GPE) "Comunicação Política e Qualidade da Democracia - Opinião pública, confiança e adesão social ao Poder Legislativo" do Centro de Formação e Aperfeiçoamento da Câmara dos Deputados (CEFOR). Agradeço ao professor José Álvaro Moisés (USP), pela consultoria ao projeto e ao coordenador do GPE, João Luiz Marciano, pela ajuda na elaboração da amostra, questionário e primeiras análises estatísticas. Agradeço ainda à colaboração e ao empenho da equipe do Serviço de Visitação da Coordenação de Relações Públicas da Câmara dos Deputados. Agradeço também a Vivian Rodrigues de Oliveira pela tabulação dos dados e a Ricardo Braga pela revisão. O trabalho contou com a valiosa ajuda de Lizie Câmara Moita de Andrade (Mestranda em Ciência Política IESP.UERJ) na elaboração dos inúmeros cálculos, quadros e regressões estatísticas. A ela, um agradecimento mais do que especial. Sem ela, este artigo, certamente, não teria sido possível.

2 O Brasil tem índice 2, em uma escala decrescente de 7 a 1 . Disponível em: <http://www.freedomhouse.org/regions/americas>. Acesso em: 23 set. 2012.

3 Tradução livre da autora do original em inglês.
} 
de uma nação", internalizada pelo aprendizado (dimensão cognitiva), pelo sentimento (dimensão afetiva) e pelas opiniões (dimensão avaliativa), forjadas pela informação disponível (ALMOND; VERBA, 1963, p. 13-14).

Assim, embora a confiança (trust) e a familiaridade sejam valores distintos, a confiabilidade e a segurança (confidence) advêm de um mundo conhecido ${ }^{4}$. As condições de familiaridade e seus limites não podem ser negligenciados quando da análise das condições de confiança (trust) (LUHMANN, 2000, p. 1), portanto. Não por acaso, o programa de visitas monitoradas da Câmara dos Deputados compõe as ações de educação cívica da instituição ${ }^{5}$ cuja folheteria convida os visitantes a conhecer a "casa de todos os brasileiros" com o slogan "pode entrar, que a casa é sua”.

A desconfiança chama particularmente a atenção da literatura quando assume caráter difuso (EAston, 1965b) em democracias em consolidação (PUHLE, 2005; LINZ; STEPAN, 1996; MERKEL, 2004), onde a falta de uma cultura cívica basilar para a cidadania ativa pode importar no mau funcionamento das instituições democráticas, pela baixa accountability societal (PERUzZOTTI; SMULOVITZ, 2006) e o agravamento das desigualdades sociais (LAGOS, 2001).

Nem toda desconfiança, no entanto, é considerada perniciosa ao regime democrático. A desconfiança política assume perspectiva positiva quando revela a emergência de "cidadãos críticos" (NORRIS, 1999; 2009; 2011; INGLEHART, 1999), ou "democratas insatisfeitos" (DAHL, 2000), mais escolarizados, bem informados e exigentes, que, egressos do mundo das necessidades (INGLEHART, 1988), aderem à democracia de forma difusa, ao mesmo tempo em que confirmam sua opção pelos princípios democráticos - pelo menos enquanto melhores do que os princípios de qualquer outro regime conhecido -, e criticam o desempenho institucional em caráter específico (EASTON, 1965a; 1965b), por exigirem maior atuação e melhor desempenho dos atores institucionais. Nesta dimensão, a queda dos índices de confiança nas assembleias (legislatures), ao contrário, pode indicar um potencial aumento da participação cidadã e da accountability vertical e societal (PERUZZOTTI; SMULOVITZ, 2006), como reflexo de uma cidadania autoconfiante (ALMOND; VERBA, 1963) e politicamente eficaz (LAGOS, 2001), fundamental para a democracia nas chaves representativa e participativa.

A literatura concorrente à do capital social, por sua vez, atribui a constante desconfiança no Congresso Nacional à frustração de expectativas com relação ao desempenho da instituição, avaliado pela atuação dos parlamentares, frequentemente envolvidos em denúncias de corrupção e escândalos de grande repercussão na mídia (DELLA PORTA, 2000; PHARR, 2000; POWER; JAMISON, 2005), marcada por um "forte viés anti-institucional" (PORTO, 1996). Seja como for, nas duas perspectivas, a confiança e a desconfiança nas instituições advêm do confronto do desempenho com o papel esperado das mesmas, ou seja, do conhecimento indutivo, obtido pela escolarização, pela informação e pela experiência democrática (OFFE, 1999; MoIsÉs, 2010), nesta literatura.

No Brasil, também observamos uma melhoria dos índices sociais, relacionada a uma cidadania mais crítica (HENRIQUE, 2009; 2010b; 2011), e aumento da adesão à democracia (MoISÉS, 2010; Meneguello, 2010), fundamentando um déficit democrático positivo (NoRRIS, 2011). Os dados do IBGE

${ }^{4}$ Para uma discussão sobre as diferentes acepções e versões do conceito de confiança na literatura da cultura cívica, ver Henrique (2009).

5 "Contribuir para o exercício da Cidadania e para o fortalecimento da democracia representativa" é um dos papéis institucionais constantes do Mapa Estratégico Corporativo da Câmara dos Deputados. 
HENRIQUE, A. L. O que pensa quem "bate à porta" de uma Casa que só "apanha"?...

mostram que o rendimento médio dos brasileiros que têm ao menos um trabalho remunerado vem aumentado nos últimos anos e as taxas de escolarização chegam a 97,6\% na faixa entre 6 e 14 anos (PNAD, 2009). A adesão ao regime democrático também cresceu 21 pontos percentuais entre 1989 e 2006, chegando ao patamar de 65\% (MENEGUELLO, 2007), mas a preferência democrática (na perspectiva churchilliana) apresenta características específicas, como a ambivalência (MoISÉS, op. cit.) e a valorização da dimensão eleitoral e do voto como forma de accountability vertical e de intervenção na política (Meneguello, 2010). Estaria, no Brasil, o aumento da desconfiança no Legislativo atrelado a uma exigente e rigorosa avaliação do desempenho parlamentar por cidadãos mais escolarizados e com maior renda como ocorre nas democracias de onde a literatura provém? Para responder a esta pergunta, é preciso saber o quê o cidadão brasileiro entende como missão do Congresso Nacional e do parlamentar e quais parâmetros ou meios utiliza para avaliar o desempenho - ou seja, como avalia a instituição, pergunta normalmente relevada pelas pesquisas. O survey que fundamenta o presente artigo, ao incluir estas duas dimensões no questionário, pretende preencher esta lacuna.

Como ponto de partida da análise, a pesquisa se debruça sobre um paradoxo instigante: a constatação de que ao mesmo tempo em que o Congresso Nacional permanece entre as instituições menos confiáveis e mais criticadas pela opinião pública, o número de participantes do programa de visitas monitoradas ao Congresso Nacional cresce anualmente: 30,87\% de $2004^{6}$ a 2009 (ano de início do survey). O que faz com que quase 180 mil pessoas (dados de 2009) procurem uma instituição que reprovam tão fortemente? Até que ponto os escândalos têm um efeito colateral interessante ao aguçar a "curiosidade" do cidadão sobre a instituição que o representa? Seria a procura decorrente apenas do aumento do turismo nacionalmente?

A Secretaria de Turismo não dispõe de uma série histórica do número de turistas que procuraram o Distrito Federal no mesmo período. Já que o público da pesquisa é o turista brasileiro, uma boa proxy pode ser o número de desembarques nacionais de passageiros no aeroporto de Brasília, que subiu 10,21\% entre 2004 e 2009, de acordo com dados do Ministério do Turismo ${ }^{7}$. Já se tomarmos por base a movimentação (embarques e desembarques) de voos domésticos no período, o aumento é de $21,78 \%$, de acordo com a Infraero 8 . Com base nestes dados, podemos inferir que a procura pela visita ao Congresso Nacional aumentou em proporção maior do que o turismo em Brasília. Não há como mensurar os reais motivos da procura. A multidimensionalidade do fenômeno dificulta a determinação da variável independente, mas a aplicação de survey entre os visitantes do Congresso Nacional pode ao menos começar a decifrar o "enigma" ao captar as orientações daqueles que cada vez mais "batem à porta" de uma instituição que, como se diz popularmente, só "apanha” da opinião pública brasileira.

Este tipo de sondagem é bastante frequente em estudos de Mercadologia, de Administração e de Comunicação, que investigam a percepção da qualidade do produto/serviço e o grau de satisfação do cliente. Há também trabalhos que analisam os programas de visitação na área do Turismo ou, no caso

\footnotetext{
${ }^{6}$ Em abril de 2004, a visitação, feita até então separadamente no Senado Federal e na Câmara dos Deputados, foi unificada. Por isso, 2004 foi escolhido como marco da série histórica de visitantes.

7 Em 2004, 5.344.474 passageiros desembarcaram em voos domésticos no Aeroporto Juscelino Kubitschek. Em 2009, este número subiu para 5.890.166. Fonte: Anuário Estatístico Embratur, volumes 32 e 37.

8 O número de passageiros em voos domésticos no Aeroporto Internacional de Brasília foi de 9.900.520, em 2004. Em 2009, este número subiu para 12.056.606. Fonte: Movimento Operacional Acumulado da Rede Infraero. Disponível em: <http://www.infraero.gov.br/index.php/br/estatistica-dos-aeroportos.html>. Acesso em: 11 ago. 2013.
} 
do Congresso Nacional, do Turismo Cívico. Em se tratando de uma instituição central para a democracia, no entanto, a "satisfação do cliente" sai da arena da simples opinião pública, migrando para a seara da educação cívica como fator relevante para a qualidade da democracia. Em outras palavras, adentra conteúdos da Ciência Política.

Viu-se que, na abordagem culturalista, o conhecimento do papel institucional, assim como o estabelecimento de laços afetivos com as instituições importam para a formação de uma cultura cívica e, por esta via, para a qualidade da democracia (HENRIQUE, 2010a). Nesta perspectiva, as orientações reveladoras da cultura política, por sua vez, são "captadas" por surveys entre os cidadãos (ALMOND; VERBA, 1963). A pesquisa entre os visitantes do Congresso Nacional ancora-se, portanto, nesta literatura.

Até que ponto o conhecimento das dependências do Palácio do Congresso Nacional, o contato físico, a familiaridade com o local de trabalho do representante e o acesso à informação sobre o processo legislativo e sobre o funcionamento da instituição, disponibilizado pela visita, influenciam a percepção da mesma pelo cidadão? Há carência de estudos sobre os programas de visitação como ferramentas de educação para a democracia. Neste artigo, a análise das percepções e orientações dos visitantes teve como objetivo preencher esta lacuna da literatura da Ciência Política.

\section{O Programa de Visitas Monitoradas ao Congresso Nacional}

Fruto de uma parceria entre as coordenações de Relações Públicas da Câmara dos Deputados e do Senado Federal, o "Visite o Congresso" é um programa de visitas monitoradas para turistas estrangeiros, brasileiros, estudantes de todos os níveis de ensino, além de grupos organizados. As visitas partem do Salão Negro do Congresso Nacional, de meia em meia hora, das 9h30 às $17 \mathrm{~h}$, todos os dias, inclusive nos finais de semana. O objetivo do programa é a educação cívica, a promoção da participação ativa do cidadão, a melhoria da imagem e da percepção de desempenho da instituição e, por esta via, da qualidade e legitimidade do regime. Para tanto, os visitantes recebem informação sobre a organização política brasileira, o processo legislativo e as formas de participação e de interação com o Legislativo, além de dados sobre a arquitetura e as obras de arte dispostas no Palácio do Congresso Nacional.

Mais de 135 mil pessoas participaram do programa "Visite o Congresso" em 2004, número que subiu para 145.208 em 2005 - ano marcado por recordes em reprovação ao desempenho dos parlamentares na esteira da divulgação do escândalo do mensalão ·, chegando a 177.632 visitantes em 2009 - número base do survey ${ }^{9}$.

\section{O Perfil do Visitante (população)}

O número de visitantes é bem distribuído entre dias de semana e finais de semana: em média, $52 \%$ e $48 \%$, respectivamente. As estatísticas são classificadas em estudante, turista brasileiro, turista estrangeiro e grupo organizado ${ }^{10}$ (com objetivo específico). A maior parte do público (cerca de $80 \%$ ) é composta por turistas brasileiros, chamados de "visitantes espontâneos", porque acorrem ao Congresso Nacional com o objetivo de conhecer a instituição sem outro propósito específico. Em segundo lugar, estão os estudantes (15\%). Nesse caso, percentuais oscilam durante os meses do ano, dependendo do

${ }^{9}$ Os números referem-se aos dados fornecidos pela Coordenação de Relações Públicas da Câmara dos Deputados utilizados como base para o survey, em 2009.

${ }^{10}$ Esta classificação comporta os grupos que não se enquadram nas categorias anteriores, como os organizados pela própria Câmara para a ambientação de funcionários novos ou para treinamento. 
HENRIQUE, A. L. O que pensa quem "bate à porta" de uma Casa que só "apanha"?...

calendário escolar. O turista estrangeiro representa o terceiro grupo, com menos de $5 \%$. 0 percentual de grupos organizados que não se enquadram nas demais categorias é insignificante. Entre as instituições atendidas, $88 \%$ são de ensino, sendo 51,14\% delas de Ensino Fundamental, 18,18\% de Ensino Médio e $30,68 \%$ de Ensino Superior.

\section{A Metodologia da Pesquisa e Seleção da Amostra}

O objetivo inicial da pesquisa era conhecer a percepção do público que literalmente "bate à porta" do Congresso Nacional, em outras palavras, o chamado visitante espontâneo. Diferentemente dos grupos organizados, estes visitantes não recebem qualquer orientação prévia por parte dos organizadores sendo, por isso, escolhidos para avaliar o impacto da visita.

A pesquisa foi aplicada, diariamente, no Salão Negro, local de onde partem os grupos monitorados. Para garantir a aleatoriedade e a liberdade de opinião nas respostas, os questionários foram dispostos em display de acrílico sobre a bancada onde os visitantes normalmente preenchem postais do Congresso Nacional, afastada, portanto, do balcão dos monitores, que abordavam os visitantes antes ou depois da visita para convidá-los a responder uma "pesquisa acadêmica de adesão espontânea", realizada de forma anônima e sem qualquer ajuda ${ }^{11}$. Os questionários podiam ser respondidos antes ou depois da visita, nunca antes e depois da visita pela mesma pessoa, garantindo, desta forma, duas amostras aleatórias distintas.

Inicialmente, foram aplicados questionários exploratórios com perguntas abertas, que depois foram fechadas com as opções mais frequentes entre os visitantes (Cf. Apêndice 1). Foram testadas 11 versões de questionários até a versão final: um questionário, com 34 questões, em sua maioria perguntas de múltipla escolha (Cf. Apêndice 2), ou seja, preponderantemente estruturado. Para facilitar a análise comparada, foram usadas perguntas e categorias idênticas ou próximas às das pesquisas " $A$ Desconfiança dos Cidadãos das Instituições Democráticas"12 e Datafolha.

\section{A Metodologia de Análise dos Dados do Survey}

Os dados tabulados foram analisados em complexidade crescente. Inicialmente, as repostas às 34 questões foram distribuídas em tabelas de frequência para verificar o perfil da amostra e os percentuais brutos de orientações dos visitantes. Em seguida, a associação entre avaliação de desempenho dos parlamentares (qualificada) e a confiança em cada uma das instituições (qualificada) foi testada com relação à escolaridade (variável independente chave na literatura). Como se trata de variáveis categóricas qualitativas, adotou-se um método mais parcimonioso para avaliar a relação entre elas: a análise das tabelas de contingência (crosstabs), dos quadros de diferença entre frequências observadas e esperadas e a aplicação do teste de qui-quadrado. A regressão múltipla de variáveis associadas nos primeiros testes de correlação só foi usada como ferramenta inicial de exploração. A assunção de seus resultados como explicativos importaria em ainda maior discretização artificial de variáveis não quantitativas, categóricas e subjetivas, o que, a meu ver, não seria parcimonioso.

\footnotetext{
${ }^{11}$ Quando solicitado, o monitor podia atuar como ledor, no caso de visitantes analfabetos ou com baixa escolaridade, desde que sem acompanhante apto para tanto. Somente eram aceitos um representante por unidade familiar.

12 Survey nacional aplicado a 2004 eleitores brasileiros em junho de 2006, coordenado pelos professores Dr. José Álvaro Moisés (NUPPs e DCP.USP) e Dra. Rachel Meneguello (CESOP e DCP.Unicamp) e apoiado pela FAPESP.
} 
Desta forma, os quadros de frequências esperadas e observadas foram escolhidos como principal fonte de análise de dados, mesmo porque a construção do questionário e a tabulação da pesquisa foram feitas de forma a identificar outras variáveis explicativas para possibilitar uma análise mais rica do conteúdo. A tabulação separou, por exemplo, as categorias de não-opinião: "não sei" e "não respondeu". A opção foi proposital. A não-resposta pode representar muito mais do que o simples desconhecimento. Pode refletir uma forma de protesto, o cansaço ou mesmo à rejeição à pesquisa, por exemplo. Observa-se no Gráfico 1 que a opção pela não-resposta é consideravelmente maior nas questões finais (31 a 34), só respondidas após a visita:

Gráfico 1

Frequência de questionários não respondidos por questão (\%)

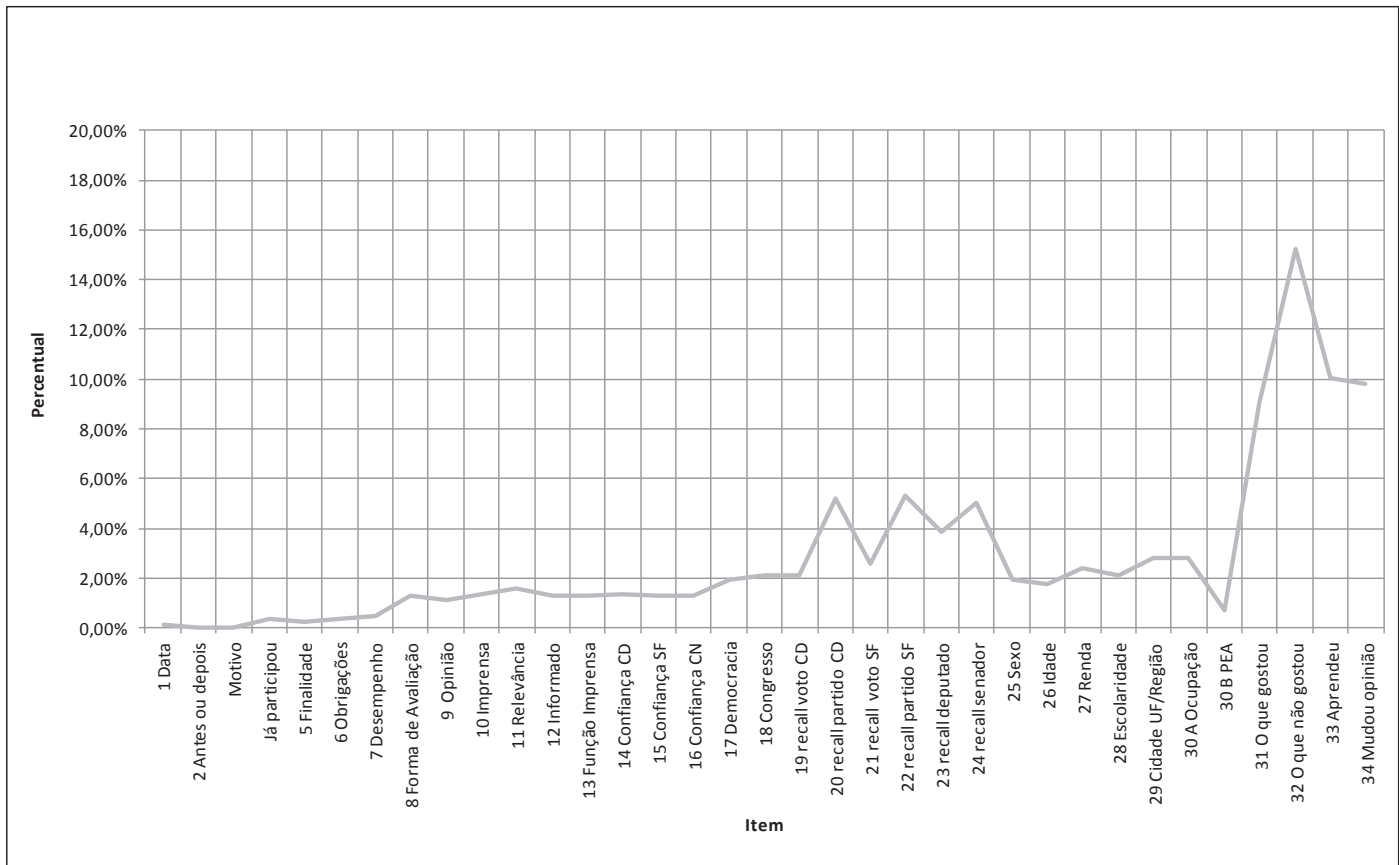

Fonte: elaboração da autora.

Para garantir maior segurança dos resultados, as categorias "não-resposta" e "não sei" foram descartadas e o teste foi refeito nos casos onde a diferença entre a não-opinião observada e esperada foi alta. De outra forma, a diferença entre o observado e o esperado em uma categoria não relevante para a análise poderia elevar "artificialmente" o valor do teste de qui-quadrado, gerando risco de "dependência espúria", como será demonstrado oportunamente.

Para buscar as possíveis implicações do contato com a instituição e do conteúdo informacional da visita sobre as orientações dos entrevistados, passou-se à aplicação de testes de qui-quadrado e à análise de quadros de frequências observadas e esperadas de percepção de desempenho, de confiança institucional e de adesão à democracia entre os que responderam antes e depois do programa e entre os que participaram de visitas anteriores. As análises das tabelas de contingência entre os que haviam 
HENRIQUE, A. L. O que pensa quem "bate à porta" de uma Casa que só "apanha"?...

visitado em outra oportunidade (visita anterior), no entanto, foram descartadas, já que os testes não rejeitaram a hipótese de independência com segurança. O motivo é simples. Houve uma sensível redução da amostra, nestes casos, especialmente quando controlado por outras variáveis pouco frequentes. A maior parte dos entrevistados visitava o Congresso Nacional pela primeira vez (71\%). Assim, a amostra de visitantes que participaram de visitas anteriores era de apenas 123 questionários. Entre eles, apenas dois tinham Ensino Fundamental, ambos com avaliação positiva, por exemplo. Os estatísticos ponderam que o tamanho da amostra $(n)$ é fundamental para a segurança da independência. "Quanto maior for o valor do $n$ tanto mais facilmente se descobre uma falta de independência" (HOEL, 1989, p. 287).

Outros testes foram aplicados para maior segurança em variáveis consideradas importantes. No caso da confiança na Câmara dos Deputados, devido ao baixo valor do qui-quadrado, calculou-se a razão de chance, ou seja, a probabilidade de um visitante confiar na instituição antes e depois da visita, respectivamente.

\section{Perfil da Amostra}

O objetivo inicial era uma amostra aleatória simples, sem cotas, de 384 questionários, com margem de erro de 2.5 pontos percentuais. A princípio, acreditava-se que, pela extensão do questionário e pelo desinteresse, haveria um baixo índice de resposta. O campo ocorreu entre outubro de 2009 e janeiro de 2010. Neste período, 432 questionários foram respondidos, sendo que, mesmo após a retirada da urna, alguns visitantes que retornaram ao Congresso Nacional posteriormente procuraram a pesquisa para preenchimento, o que denota o interesse do cidadão em ser ouvido.

Só cidadãos brasileiros acima de 16 anos, ou seja, aptos ao voto, podiam responder aos questionários.

Aleatoriamente, foram aplicados 221 questionários antes da visita e 211 questionários depois da visita, o que também garantiu amostras praticamente paritárias: $51,16 \%$ e 48,84\%, respectivamente. Trinta e seis por cento das repostas foram obtidas em dias úteis e $64 \%$ nos fins de semana. Embora a distribuição dos visitantes entre os dias úteis e finais de semana seja praticamente homogênea, o turista espontâneo é maioria nos fins de semana. O afluxo de turistas espontâneos também costuma ser maior à tarde. A metodologia da aplicação garantiu que a amostra fosse a mais fidedigna possível à população de visitantes espontâneos.

O turismo $(76,4 \%)$ e a curiosidade $(33,8 \%)$ foram apontadas como as principais razões para a visita. Dezenove por cento dos entrevistados citaram a motivação cívica e $12 \%$ o desejo de conhecer os parlamentares como razões para escolher a visita ao Congresso Nacional como atividade de lazer. Apenas 3\% dos entrevistados disseram estar ali porque tinham outro compromisso no Congresso Nacional. O questionário permitia respostas múltiplas neste item. Sendo assim, a metodologia atingiu o objetivo: entrevistar aquele que espontaneamente procura conhecer as dependências da Câmara dos Deputados e do Senado Federal.

As mulheres corresponderam a $46 \%$ dos entrevistados, contra $54 \%$ de homens ${ }^{13}$. Com relação à faixa etária, 57\% da amostra tinham até 34 anos, sendo 37,5\% dos entrevistados entre 25 e 34 anos,

\footnotetext{
${ }^{13}$ As mulheres correspondem a $51 \%$ da população e a $52 \%$ dos eleitores brasileiros (Censo e TSE, 2010).
} 
como pode ser visto no Gráfico 2. Todos os percentuais dos indicadores sociodemográficos restringem. se às respostas válidas.

Gráfico 2

Entrevistados por faixa etária (\%)

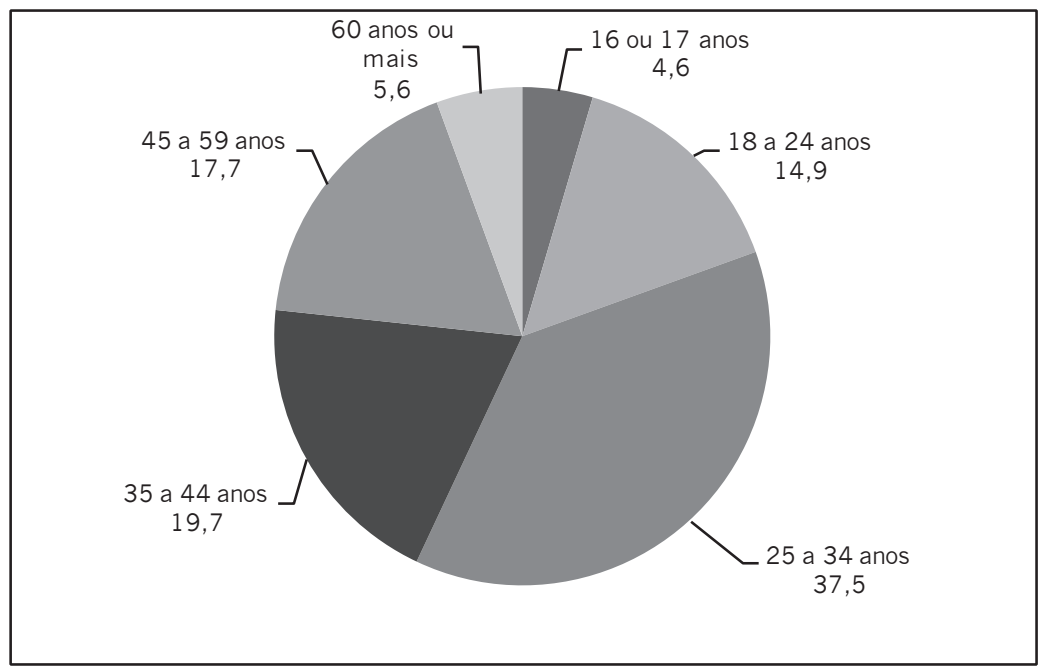

Fonte: Elaboração da autora.

A escolaridade da amostra é alta (Gráfico 3). Mais de 70\% dos entrevistados têm pelo menos Ensino Superior (superior $42,75 \%$ e 31,87\% pós-graduação), mesmo que incompleto, o que corresponde a mais de 11 anos de estudo. A população brasileira tem em média 7,6 anos de estudo (PNAD, 2009).

Gráfico 3

Entrevistados por escolaridade (\%)

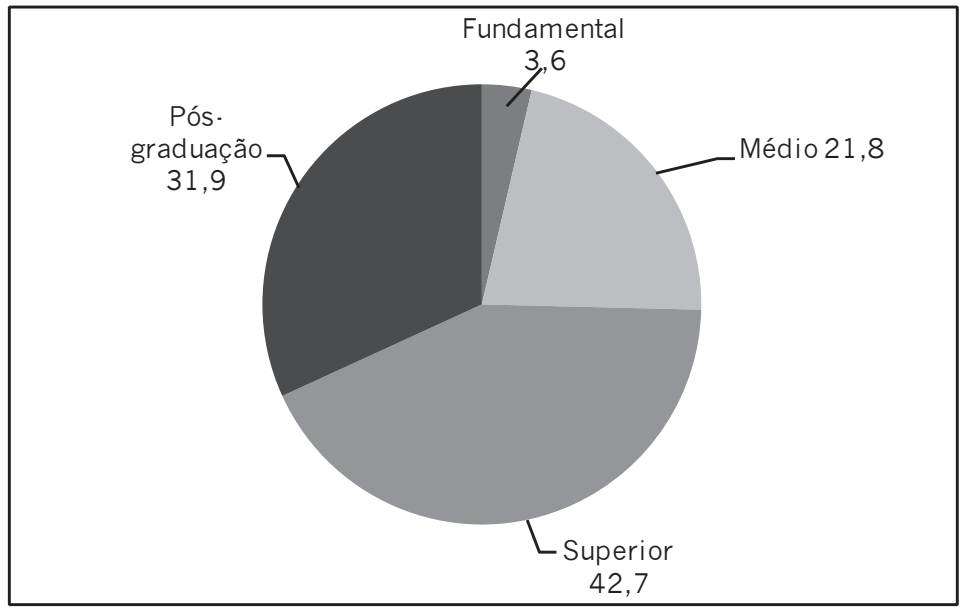

Fonte: Elaboração da autora 


\section{HENRIQUE, A. L. O que pensa quem "bate à porta" de uma Casa que só "apanha"?...}

A amostra também é, preponderantemente, de alta renda: $63,32 \%$ dos entrevistados ganham mais de 5 salários mínimos, sendo que destes, metade tem renda superior a 10 salários mínimos, como pode ser visto no Gráfico 4. Quase 33\% da população brasileira ganham um salário mínimo e apenas 3\% ganham mais de 10 salários mínimos, de acordo com o Censo 2010.

Gráfico 4

Entrevistados por renda (\%)

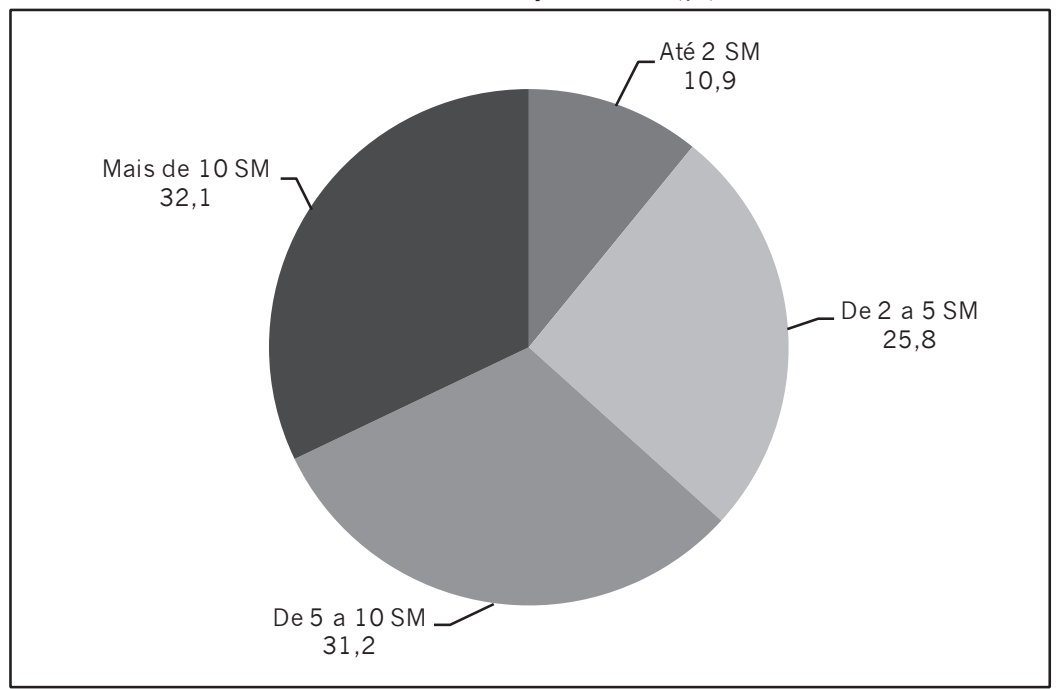

Fonte: Elaboração da autora.

A maior parte dos entrevistados mora em capitais e regiões metropolitanas (70\%), sendo quase 23\% do próprio Distrito Federal, seguido do estado de São Paulo (17,5\%) e do Rio de Janeiro (9\%). Interessante observar que apenas $7 \%$ dos entrevistados vieram de Goiás, estado limítrofe. Finalmente, mais de $80 \%$ dos entrevistados estão na População Economicamente Ativa (PEA) ${ }^{14}$.

\section{A Missão do Congresso Nacional e o Papel dos Parlamentares}

Ao contrário da confiança horizontal, estabelecida entre indivíduos em relações onde são percebidos como iguais, a confiança vertical e, em particular a confiança política, forma-se em relações percebidas assimetricamente ${ }^{15}$ entre pessoas animadas e instituições ou entre pessoas e representantes, sejam eles simbólicos - standing for representation (PITKIN, 1967) ·, ou mandatários (como os parlamentares), o que aumenta a multidimensionalidade do fenômeno. Logo, enquanto a confiança horizontal depende da interação e da reciprocidade, a confiança vertical remete à segurança. Desta forma, confiar em instituições implica em saber que suas regras, valores e normas são compartilhados e obedecidos pelos seus operadores. Implica também em acompanhar a informação sobre o desempenho dos mesmos. Mais do que ao relacionamento, a confiança política está, portanto, intimamente ligada à confiabilidade da instituição política e à credibilidade dos seus agentes, mensurada pela opinião

14 A PEA corresponde à "potencial mão-de-obra". São excluídas, portanto, as pessoas incapacitadas para o trabalho, os desempregados há mais de um ano (desalentados), os estudantes e as donas de casa.

15 Para uma melhor compreensão da terminologia, ver Henrique (2009, p. 38-40; 2010c). 
declinada em surveys. Nesta chave, o cidadão precisa conhecer o papel institucional e de seus atores para que possa avaliar o desempenho. Daí a importância da informação e da escolarização.

De acordo com os resultados do survey, a principal função do Congresso Nacional percebida pelo visitante é legislar (79,9\%), seguida por representar (50,2\%), e por fórum de debate (40,3\%), como pode ser visto no Gráfico 5. Importante lembrar que o questionário permitia respostas múltiplas, e, portanto, os percentuais ultrapassam cem por cento.

Gráfico 5

Finalidade do Congresso Nacional (\%)

Out. 2009 / Jan. 2010

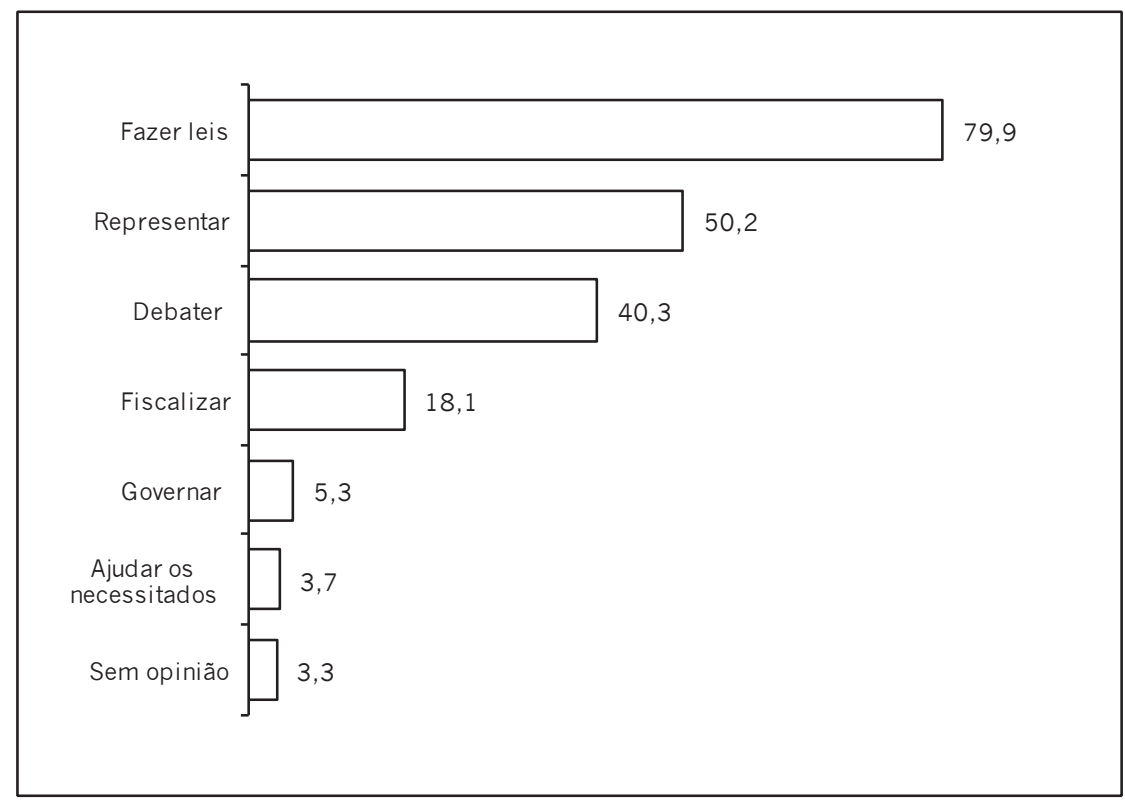

Fonte: Elaboração da autora.

É fácil perceber porque a função legiferante é a primeira lembrança. Ela está no próprio nome do poder "Legislativo", sendo também a mais reforçada pela imprensa na avaliação da "produtividade" do Congresso Nacional. Importante observar que o cidadão percebe a função representativa, uma função relevada pela maioria das pesquisas. Também percebe o Congresso como uma "casa debatedora", enquanto boa parte da mídia demanda "produção". A função fiscalizadora - outra função comumente esquecida - foi apontada por $18 \%$ dos entrevistados.

Da mesma forma, para o visitante, legislar é a principal função dos parlamentares $(81,3 \%)$, seguida de representar (46,8\%). A função de "despachante" (ajudar a resolver problemas em órgãos públicos) também é apontada por $11,8 \%$, como pode ser visto no Gráfico 616:

${ }^{16}$ Entre as "outras obrigações" percebidas (6\%), a questão da ética, da probidade e do combate à corrupção aparece em $1 / 4$ das respostas. 
HENRIQUE, A. L. O que pensa quem "bate à porta" de uma Casa que só "apanha"?...

Gráfico 6

Obrigação dos Deputados e Senadores (\%)

Out. 2009 / Jan. 2010

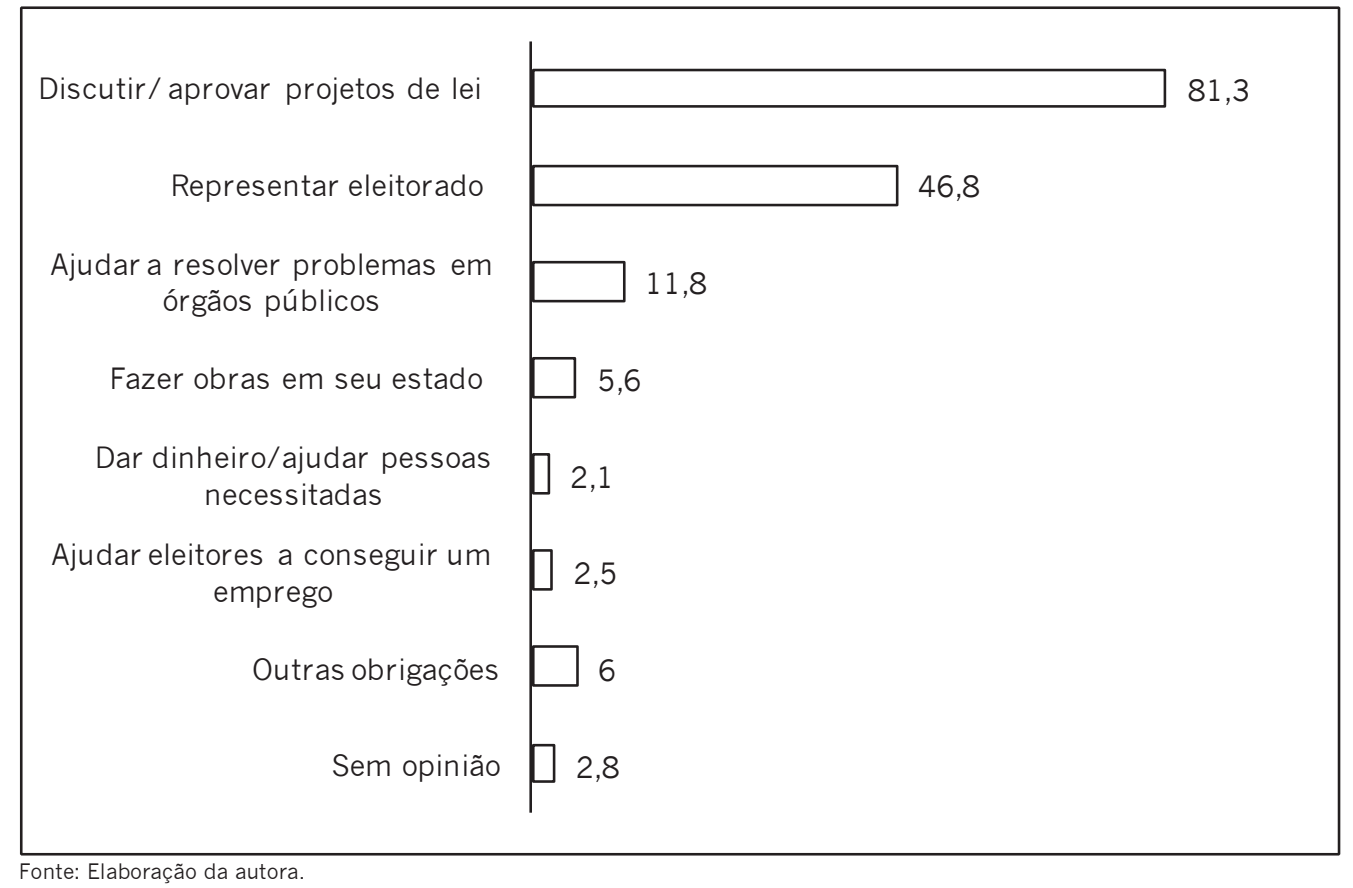

\section{A Avaliação de Desempenho dos Parlamentares}

A pesquisa replicou a pergunta do Instituto Datafolha que avalia o desempenho dos parlamentares: "Você acha que os deputados e senadores que estão atualmente no Congresso estão tendo um desempenho: ótimo, bom, regular, ruim ou péssimo?" As categorias foram agrupadas (desempenho qualificado) em positivo (somatório das categorias ótimo e bom), regular, e negativo (somatório das categorias ruim e péssimo). Conforme esperado, a maior parte dos visitantes $(51,2 \%)$ não está contente com o trabalho desenvolvido pelos representantes; 34,5\% o classificam como regular; $9 \%$ como positivo, $3 \%$ não sabiam e $2,3 \%$ não responderam.

Os percentuais são bem próximos aos encontrados por outras pesquisas, particularmente à média dos índices do Datafolha (2005/2010) para o segmento de escolaridade superior ou acima (9\%, positivo; $37 \%$ regular; $53 \%$ negativo; $3 \%$ sem opinião) $)^{17} 18$.

Conforme apontado pela literatura mundialmente, também nesta amostra são os mais escolarizados aqueles que mais reprovam o desempenho dos parlamentares (Gráfico 7), o que, mais uma vez, corrobora achados de outras pesquisas que revelam a existência de uma cidadania crítica (NORRIS, 1999; 2009; 2011) também no Brasil (MENEGUELLo, 2007; 2010).

\footnotetext{
${ }^{17}$ Média dos índices de avaliação de desempenho dos parlamentares da Pesquisa Datafolha entre 2005 e 2010. Dados disponíveis em: <http://datafolha.folha.uol.com.br/opiniaopublica/avaliacaodegoverno/congressonacional/eleitosem2006/indice-1.shtml>. Elaboração da autora.

${ }^{18}$ Para uma análise mais detalhada dos índices de avaliação de desempenho dos parlamentares entre os diferentes segmentos de escolaridade no período de 2005 a 2008, ver Henrique (2009; 2010b).
} 
OPINIÃO PÚBLICA, Campinas, vol. 19, n², novembro, 2013, p. 346-379

Entre os menos escolarizados, a aprovação sobe para $28,6 \%$ e a reprovação cai para $14,3 \%$. Já entre os que têm pós-graduação, a avaliação positiva cai para $4,1 \%$ e a avaliação negativa sobe para $60,2 \%$. A avaliação regular é semelhante entre os dois níveis mais altos de escolaridade. A opção "regular" costuma ser um "refúgio" para a indecisão e a não-opinião, por isso, de difícil análise. A relação inversa entre aprovação e escolaridade e reprovação e escolaridade é evidente no Gráfico 7:

\section{Gráfico 7}

Avaliação do Desempenho dos Parlamentares por Escolaridade (\%)

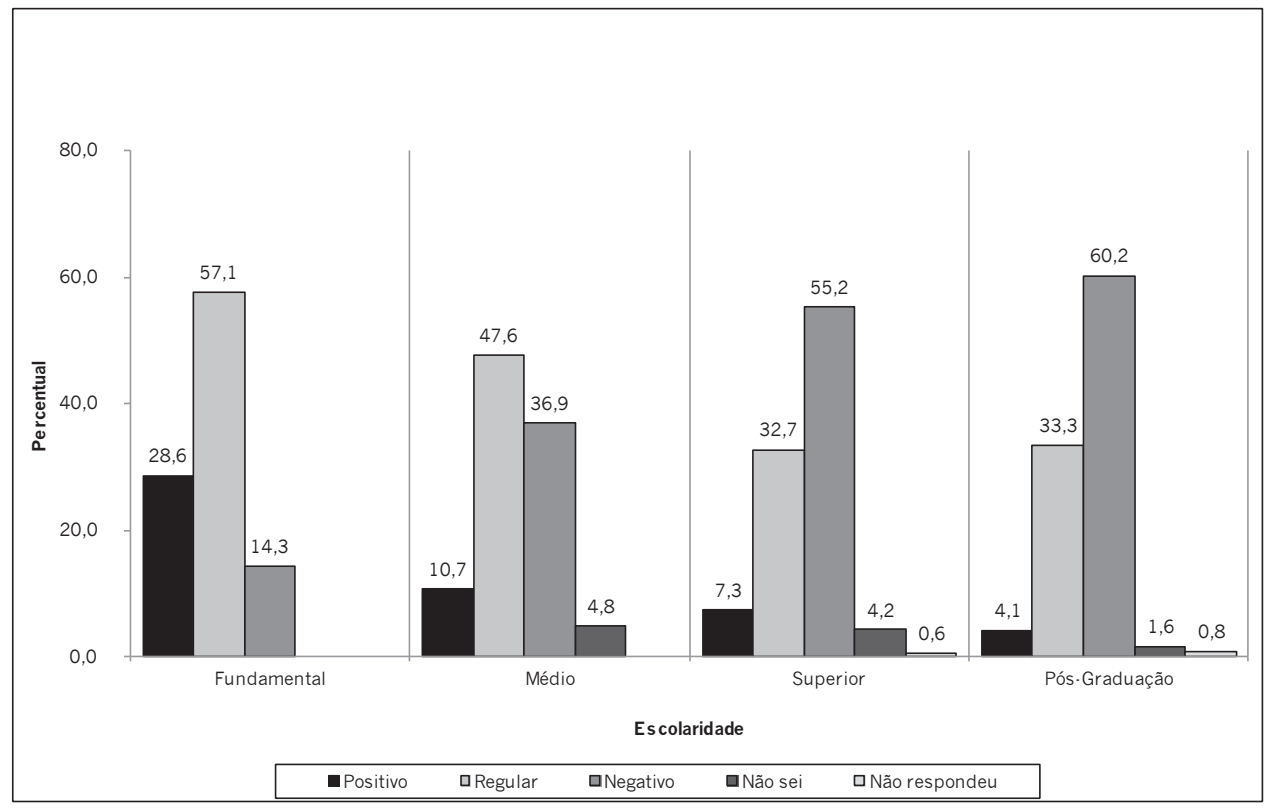

Fonte: Elaboracão da autora.

A correlação entre desempenho qualificado e escolaridade na amostra foi significativa, mas fraca $(0,194)$, a $99 \%{ }^{19}$. Para entender melhor a relação entre as duas variáveis categóricas, partiu-se para o teste de qui-quadrado e a análise das frequências esperadas e observadas (Quadro 1).

Quadro 1

Diferença entre a frequência observada e a frequência esperada na amostra para Avaliação do Desempenho dos Parlamentares Qualificada e Escolaridade 20

\begin{tabular}{|l|c|c|c|c|c|}
\hline \multicolumn{5}{|c|}{ Avaliação de Desempenho dos Parlamentares Qualificada } \\
\hline \multicolumn{1}{|c|}{ Escolaridade } & Positiva & Regular & Negativa & Não sei & Não respondeu \\
\hline Fundamental & 2,108003108 & 0,62701 & $-0,72576$ & $\cdot 1$ & -1 \\
\hline Médio & 0,189532117 & 0,3838 & $-0,27695$ & 0,586043 & -1 \\
\hline Superior & $-0,194522755$ & $-0,0513$ & 0,077918 & 0,409585 & $-0,738219895$ \\
\hline Pós-Graduação & $-0,550157445$ & $-0,0345$ & 0,174883 & $-0,46019$ & $-0,649122807$ \\
\hline Não sei & -1 & -1 & 1,262443 & -1 & -1 \\
\hline Não respondeu & 1,218934911 & $-0,6128$ & $-0,04281$ & $\cdot 1$ & 6,692307692 \\
\hline
\end{tabular}

190.01 level (2-tailed)

20 Os valores encontrados em cada célula correspondem ao resultado da diferença entre a Frequência Observada e a Frequência Esperada dividido pela Frequência Esperada ( $F o \cdot F e) / F e$. No cálculo do $X^{2}$, a diferença ( $\left.F o \cdot F e\right)$ é elevada ao quadrado. $O$ procedimento torna todos os resultados positivos, o que inviabilizaria a análise da direção do desvio. 


\section{HENRIQUE, A. L. O que pensa quem "bate à porta" de uma Casa que só "apanha"?...}

O teste qui-quadrado permite-nos descartar a independência das variáveis com segurança $\left(x^{2}=\right.$ $95,28)^{21}$. No Quadro 1, no entanto, observa-se uma alta diferença entre a frequência observada e a esperada de não-resposta às duas questões $(6,692)$, o que poderia gerar uma dependência espúria (Cf. item "A Metodologia de Análise dos Dados do Survey"). Por isso, o teste foi refeito excluindo-se os valores de "não-resposta" de ambas as variáveis. Adotou-se o mesmo procedimento parcimonioso em todos os cálculos em que esta suspeita ocorreu.

\section{Quadro 2}

Diferença entre a frequência observada e a frequência esperada na amostra para Avaliação do Desempenho dos Parlamentares Qualificada e Escolaridade

\begin{tabular}{|l|c|c|c|c|}
\hline \multicolumn{5}{|c|}{ Avaliação de Desempenho dos Parlamentares Qualificada } \\
\hline \multicolumn{1}{|c|}{ Escolaridade } & Positiva & Regular & Negativa & Não sei \\
\hline Fundamental & 2,666667 & 0,538462 & $-0,72362$ & -1 \\
\hline Médio & 0,375 & 0,282051 & $-0,28601$ & 0,410256 \\
\hline Superior & $-0,06098$ & $-0,11351$ & 0,073508 & 0,264071 \\
\hline Pós-Graduação & $-0,47404$ & $-0,09521$ & 0,17349 & $-0,5145$ \\
\hline Não sei & -1 & -1 & 0,934673 & -1 \\
\hline
\end{tabular}

Mesmo sem a não-resposta, o valor do teste de qui-quadrado permite que a independência das variáveis seja refutada com segurança ${ }^{22}$. A escolaridade importa para a avaliação de desempenho, particularmente entre os menos escolarizados. A análise do Quadro 2 mostra que a aprovação é maior do que a esperada entre os menos escolarizados, particularmente os que têm Ensino Fundamental, enquanto os visitantes com nível Superior ou com Pós-Graduação tendem a orientações mais críticas. Os valores negativos (-1) não foram considerados na análise porque representam a ausência de frequência observada naquela categoria.

Ocorre que, conforme ponderam Diamond e Morlino (2005, p. XI), a forma como as pessoas percebem a qualidade não necessariamente decorre de uma análise do "processo" e do "conteúdo". Tomando emprestada a terminologia da Administração Mercadológica, de onde o conceito se origina, isto significa dizer que, embora o "produto final" atenda a todas "especificações", ainda assim a "satisfação do cliente" dependerá de outras variáveis intangíveis. Desta forma, ao contrário do que advoga a literatura (OFFE, 1999), a avaliação de desempenho pode não derivar somente da percepção do trabalho parlamentar dentro da instituição.

Para testar esta hipótese, a pesquisa agregou uma perspectiva nova aos surveys introduzindo a pergunta "Como o(a) senhor(a) avalia o desempenho do Congresso Nacional?" De fato, a maioria dos entrevistados avalia o desempenho institucional pelo trabalho dos deputados e senadores (51,2\%), mas as atitudes dos parlamentares, mesmo fora do ambiente de trabalho, importam - e muito - nesta avaliação (42,8\%), conforme mostra o Gráfico 8. Este é um achado importante da pesquisa, que merece maior investigação empírica.

\footnotetext{
${ }^{21} \mathrm{~N}=432$. O parâmetro para 20 graus de liberdade é de 37,6 para $1 \%$ de significância.

$22 \mathrm{~N}=385 \mathrm{X}^{2}=29,1$, graus de liberdade $=12$, ponto crítico $26,217 \mathrm{p}=1 \%$
} 


\section{Gráfico 8}

Como avalia o desempenho do Congresso Nacional (\%)

Out. 2009 / Jan. 2010

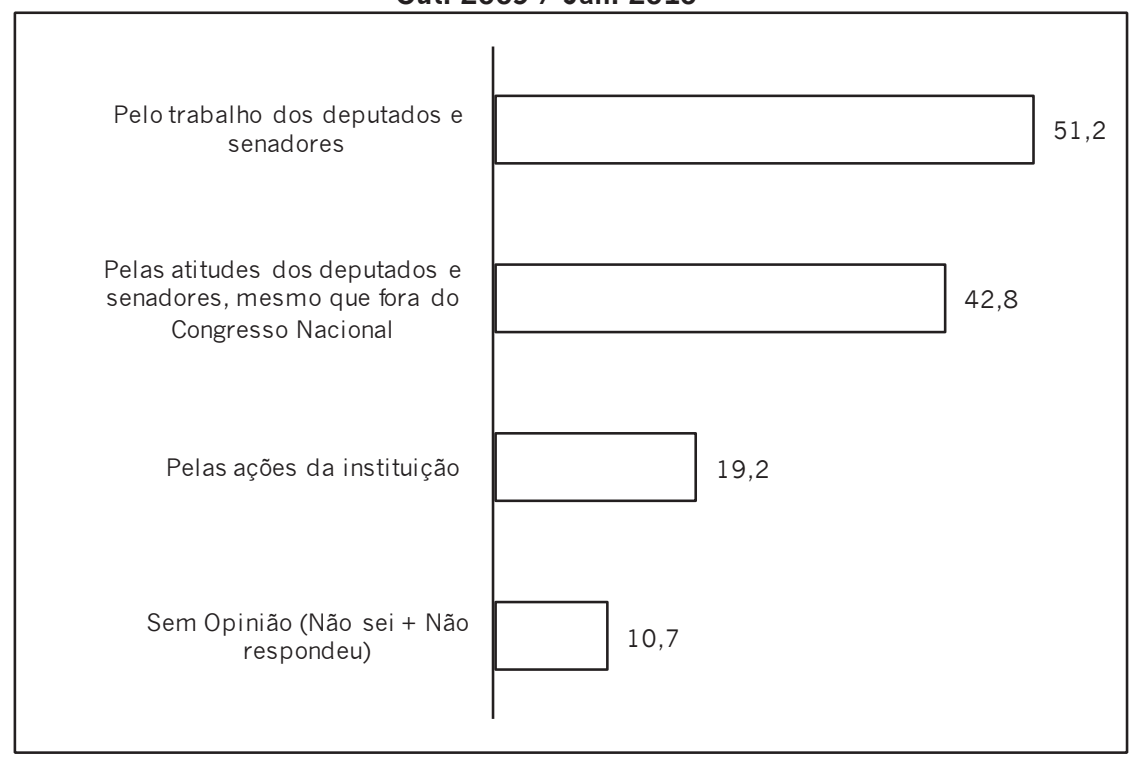

Fonte: Elaboracão da autora.

Os resultados revelaram ainda outro dado importante: 19,2\% dos visitantes também avaliam o Congresso Nacional pelas ações institucionais. Como no caso das "obrigações dos deputados" e da "finalidade do Congresso Nacional", a pergunta sobre como se avalia o desempenho do Congresso Nacional permite respostas múltiplas. $\mathrm{O}$ achado é particularmente relevante porque implica em dizer que os parlamentares podem não ser os únicos agentes institucionais percebidos, embora a literatura não faça menção ao corpo administrativo na avaliação de desempenho das legislatures, ao contrário do que ocorre com outras instituições (HENRIQUE, 2010c).

Pela amostra, não se pode afirmar, no entanto, que os critérios, de alguma forma, influenciem a avaliação. O valor do qui-quadrado para avaliação de desempenho do Congresso Nacional e avaliação de desempenho pelas ações da instituição é insignificante. E os testes entre desempenho e avaliação pelo trabalho dos parlamentares dentro da instituição e pelas atitudes fora dela não permitiram descartar a hipótese de independência com segurança. Assim, a análise sobre os parâmetros explicativos da avaliação de desempenho dos parlamentares ainda está longe de ser esgotada.

\section{A Confiança no Congresso Nacional}

Da mesma forma, na amostra, a confiança nas duas casas do Congresso Nacional é compatível com os índices encontrados na bibliografia: em torno de 30\%. Também corroborando a revisão da literatura empírica (HENRIQUE, 2009), a desconfiança é um pouco maior com relação à Câmara dos Deputados (65,5\%), do que com relação ao Senado Federal (62,5\%). A desconfiança no Congresso Nacional, como um todo, é ligeiramente menor: $58,1 \%$, embora os índices sejam bastante compatíveis. A pergunta sobre as três instituições do Legislativo em separado é proposital. Busca identificar a 
HENRIQUE, A. L. O que pensa quem "bate à porta" de uma Casa que só "apanha"?...

percepção de diferenças entre as instituições pelos cidadãos, opção incomum em surveys sobre apoio político.

Ao que tudo indica, o visitante não diferencia muito bem as casas do Congresso Nacional, conforme mostra o Gráfico 9. Esta constatação confirma a experiência reportada pelos monitores de que o visitante não consegue, muitas vezes, diferenciar o locus do trabalho não só dos deputados e senadores, como também do chefe do Executivo. Confirma também a literatura. Políticos, partidos e Congresso são percebidos e classificados pelos cidadãos comuns em uma só classe: a política (PoWER; JAMISON, 2005, p. 71).

Gráfico 9

Confiança no Congresso Nacional (\%) Out. 2009 / Jan. 2010

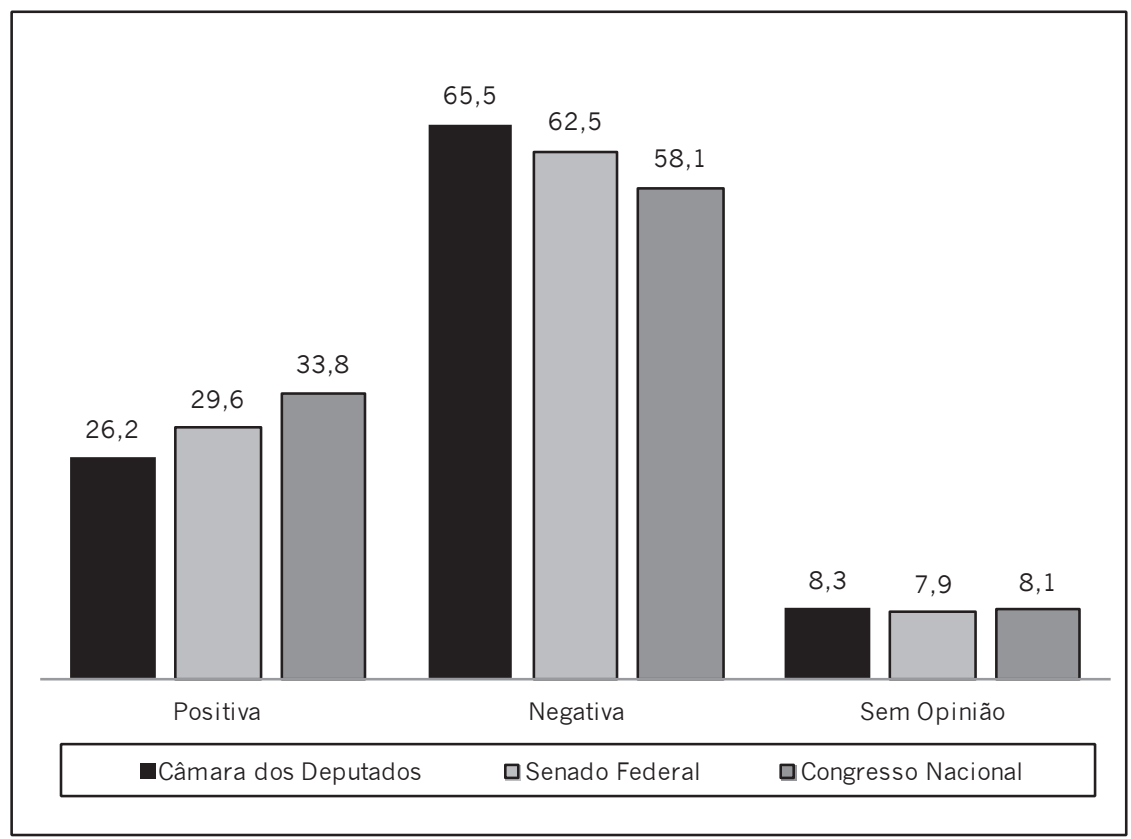

Fonte: Elaboracão da autora.

Viu-se que, de acordo com a literatura, a confiança institucional decorre de uma avaliação do desempenho dos atores: no caso do Congresso Nacional, os parlamentares (OfFE, 1999). De fato, na amostra, há uma correlação significativa positiva e baixa entre a avaliação de desempenho qualificada (variável independente) e a confiança qualificada na Câmara dos Deputados ( $r=0,328$ ), no Senado Federal $(r=0,298)$ e no Congresso Nacional $(r=0,280)^{23}$. Em outras palavras, a avaliação do trabalho dos parlamentares explica (e/ou causa) a confiança nas casas do Legislativo.

Os valores do qui-quadrado permitiram rejeitar com segurança, também nesta amostra, a hipótese de independência entre as variáveis avaliação de desempenho dos parlamentares e confiança

${ }^{23}$ Todas a 0,01 (2-tailed) 
nas casas do Congresso Nacional. Mesmo com a retirada das categorias de não-opinião24, os valores continuaram altos: $X^{2}=85,261, n=385 ; X^{2}=76,072, n=386 ; X^{2}=65,401, n=385$, para Câmara dos Deputados, Senado Federal e Congresso Nacional, respectivamente, com dois graus de liberdade, ponto crítico de 9,21, a $1 \%$.

Pela distribuição do Quadro 3, observa-se que, na amostra, entre os que avaliam o desempenho dos parlamentares positivamente, há mais indivíduos que confiam na Câmara dos Deputados $(1,506659)$ do que na hipótese de que não houvesse nenhuma relação entre as variáveis (hipótese nula). Percepção semelhante foi observada com relação ao Senado Federal $(1,636612)$ e ao Congresso Nacional $(1,086207)$.

\section{Quadro 3}

Diferença entre frequência observada e esperada para Confiança na Câmara dos Deputados Qualificada e Avaliação de Desempenho Qualificada

\begin{tabular}{|l|c|c|c|}
\hline \multicolumn{4}{|c|}{ Avaliação de Desempenho Qualificada } \\
\hline Confiança na CD Qualificada & Positiva & Regular & Negativa \\
\hline Positiva & 1,506659 & 0,630205 & $-0,64846$ \\
\hline Negativa & $-0,59502$ & $-0,24889$ & 0,256096 \\
\hline
\end{tabular}

Assim como ocorre com a avaliação de desempenho, a literatura relaciona as confianças social e política à escolaridade. Uma análise da PESB 2002 (ALMEIDA; SCHROEDER; CHEIBUB; 2002) mostra que a escolaridade aparece inversamente associada à confiança na Câmara dos Deputados (HENRIQUE, 2011). Também entre os visitantes são os menos escolarizados que mais confiam na Câmara $(57,1 \%$ contra $26,2 \%$ na amostra como um todo), no Senado (57,1\%, contra $29,6 \%$ na amostra como um todo) e no Congresso Nacional (42,9\%, contra $33,8 \%$ na amostra como um todo), como pode ser observado nos Gráficos 10,11, 12, respectivamente.

Observa-se ainda nestes gráficos que o contingente de não-resposta é maior entre os menos escolarizados, o que corrobora achados de pesquisa anterior da autora sobre os índices de avaliação de desempenho dos parlamentares do Datafolha entre 2005 e 2008. Quase sempre "invisíveis" nas pesquisas de opinião e na academia, estes contingentes são, por isso, chamados de "cidadãos ocultos" (HenRIQUe, 2009; 2010b). Pela sua invisibilidade (Honneth, 2001), exclusão e não participação, esta pode ser a mais perniciosa forma de cidadania, porque triplamente danosa para a qualidade do regime. Infelizmente, devido à reduzida amostra (n), as frequências das categorias de não-opinião controladas pela escolaridade não puderam ser levadas em conta em testes de associação nesta amostra (Cf. item "A Metodologia de Análise dos Dados do Survey").

${ }^{24}$ Além da não-resposta, retirou-se ainda a categoria "não-sei” para que não houvesse o risco de dependência espúria, já que a diferença entre a frequência observada e a esperada era alta (12,252). Mesmo assim, a independência não pôde ser descartada. 
HENRIQUE, A. L. O que pensa quem "bate à porta" de uma Casa que só "apanha"?...

Gráfico 10

Confiança na Câmara dos Deputados por Escolaridade (\%)

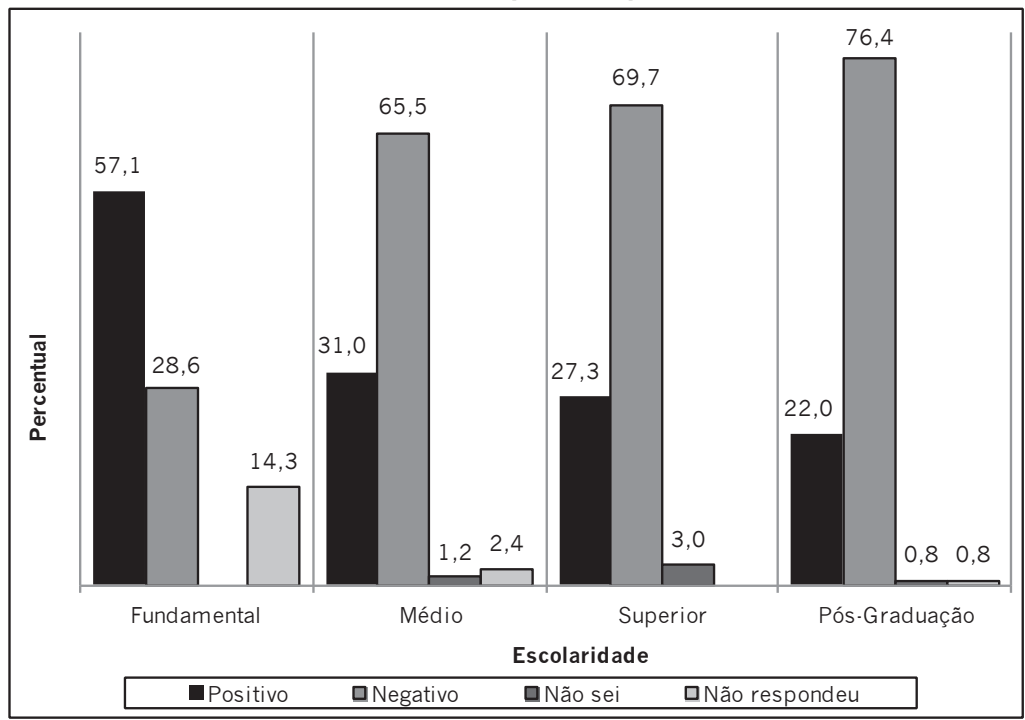

Fonte: Elaboração da autora.

Note-se que os índices de confiança e de desconfiança entre os menos escolarizados são idênticos com relação à Câmara dos Deputados (Gráfico 10) e ao Senado Federal (Gráfico 11). Provavelmente, há menor diferenciação entre as duas casas do Congresso Nacional neste segmento.

Gráfico 11

Confiança no Senado Federal por Escolaridade (\%)

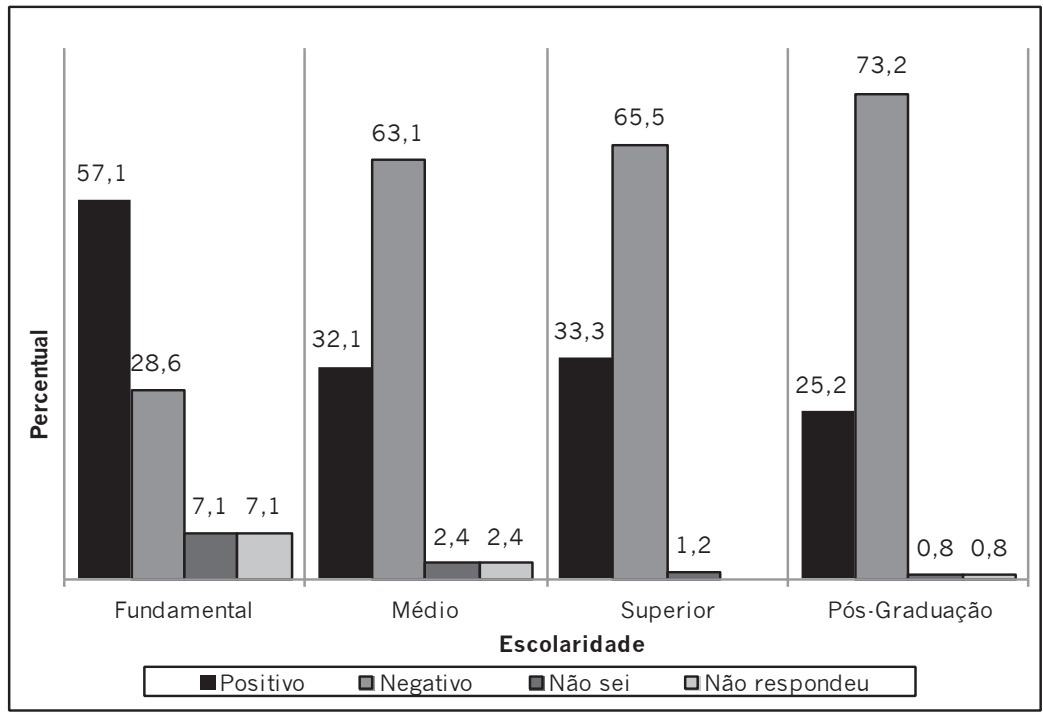

Fonte: Elaboração da autora. 
Interessante observar também que a confiança e a desconfiança no Congresso Nacional não diferem entre os menos escolarizados (Gráfico 12). 0 mesmo ocorre com a alta não-opinião, idêntica à com relação ao Senado Federal.

\section{Gráfico 12}

Confiança no Congresso Nacional e Escolaridade (\%)

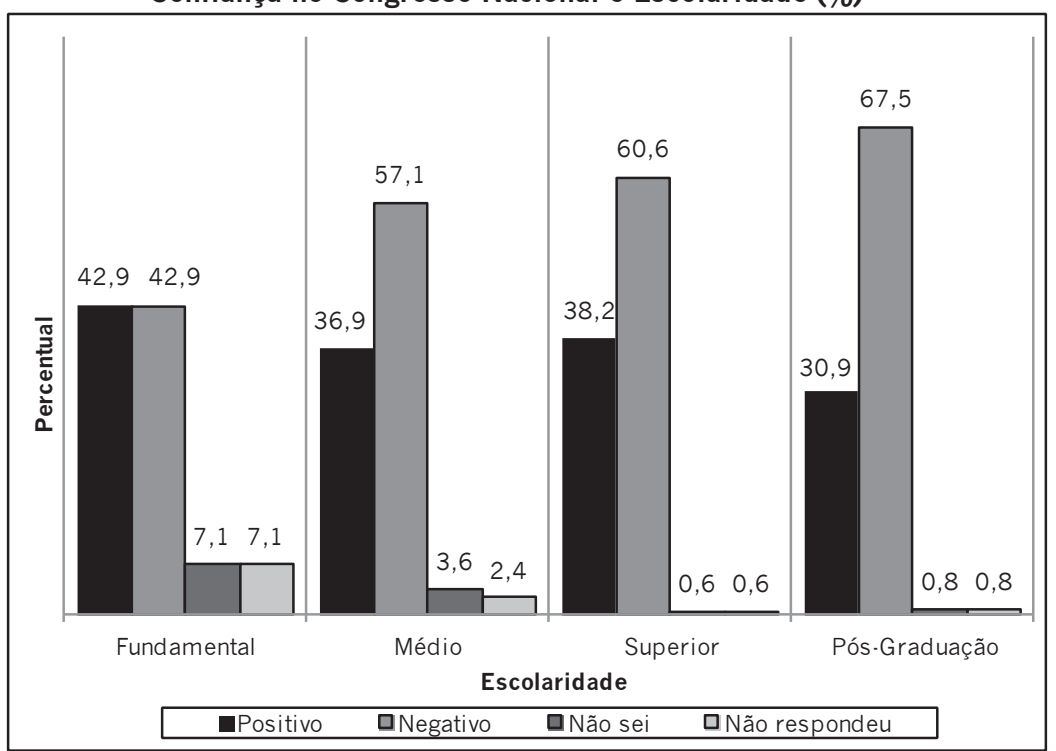

Fonte: Elaboração da autora.

No caso do Congresso Nacional, a baixa diferenciação pode decorrer da falta de capacidade cognitiva e de sofisticação intelectual para entendimento do conceito. Além da dificuldade de compreensão do termo, o Congresso Nacional é constantemente usado como acepção de "parlamentar", confusão reforçada pela mídia e, muitas vezes, até por uma desatenção na academia. É comum a divulgação dos resultados da avaliação de desempenho dos congressistas como índices de avaliação da própria instituição Congresso Nacional. Este fenômeno dá indícios, e ao mesmo tempo, reforça uma característica importante da confiança no Congresso Nacional, mais evidente com relação à Câmara dos Deputados, que mescla aspectos da confiança horizontal e vertical, em um fenômeno que classifico como "metonímia do Legislativo". A relação de confiança no parlamentar é precoce, frequentemente anterior à vida pública, e perpetua-se na campanha, conforme relatos dos próprios parlamentares, e após a posse no cargo, mesclando traços pessoais e institucionais. Importante ressaltar que, nesta mesma amostra, 42,8\% dos entrevistados declaram que as atitudes dos parlamentares, mesmo que fora do Congresso Nacional, importam para a avaliação do desempenho (Cf. Gráfico 8). A metonímia é uma figura de linguagem que consiste no emprego de um termo (a parte) por outro (o todo), e que evidencia uma relação de semelhança ou a possibilidade de associação existente na percepção subjetiva dos conceitos. Nesta chave, pode-se entender o contágio da falta de credibilidade dos parlamentares para a confiabilidade da instituição (HENRIQUE, 2010c). 
HENRIQUE, A. L. O que pensa quem "bate à porta" de uma Casa que só "apanha"?...

A literatura aponta correlação entre escolaridade e confiança nas casas do Legislativo. Também na amostra há correlação significativa e moderada entre escolaridade e confiança qualificada na Câmara dos Deputados $(0,404)$, no Senado Federal $(0,413)$ e no Congresso Nacional $(0,385)^{25}$. Devido à proximidade dos valores, à pouca diferenciação entre as duas casas e o Congresso Nacional e ao papel representativo da instituição, o artigo concentrou a análise das variáveis somente na chamada "Casa de todos os brasileiros".

Os valores do qui-quadrado descartaram a hipótese de independência entre escolaridade e confiança na Câmara dos Deputados, mas, com a exclusão da "não-resposta" (método mais parcimonioso), com menor segurança (nível de significância de $5 \%)^{26}$. A análise das frequências também mostra que a confiança na Câmara dos Deputados é maior entre os visitantes que têm Ensino Fundamental do que no caso da independência das variáveis (Quadro 4):

Quadro 4

Diferença entre frequência observada e frequência esperada para Confiança na Câmara dos Deputados Qualificada e Escolaridade ${ }^{27}$

\begin{tabular}{|l|c|c|c|}
\hline \multicolumn{4}{|c|}{ Confiança na Câmara dos Deputados Qualificada } \\
\hline \multicolumn{1}{|c|}{ Escolaridade } & Confiança Positiva & Confiança Negativa & Não sei \\
\hline Fundamental & 1,380062 & $-0,52488$ & $\cdot 1$ \\
\hline Médio & 0,131981 & $-0,04396$ & $-0,33449$ \\
\hline Superior & $-0,02634$ & $-0,00656$ & 0,65368 \\
\hline Pós-Graduação & $-0,2099$ & 0,098238 & $-0,55269$ \\
\hline Não sei & 2,570093 & -1 & -1 \\
\hline
\end{tabular}

Fonte: Elaboração da autora.

Os achados confirmam pesquisa anterior da autora. A análise dos índices de avaliação de desempenho parlamentar do Datafolha durante o período do mensalão mostra que a aprovação é maior entre os menos escolarizados e a reação ao escândalo menor, mesmo em períodos de grande repercussão de notícias negativas sobre o Congresso Nacional (HENRIQUE, 2009; 2010b; 2011). Devido à segura e direta relação entre avaliação de desempenho e confiança, confirmada na amostra e na literatura, tais cidadãos são, no trabalho citado, classificados como "cidadãos crentes", por apresentar um tipo de confiança que pouco reflete a avaliação indutiva de Offe (1999) que fundamenta a "cidadania crítica", mas que mais se assemelha à crença (LUHMANN, 2000) ou à "fé cega" (GIDDENS, 1990) no Congresso Nacional, enquanto sistema perito.

\section{O Impacto da Visita Monitorada nas Orientações dos Visitantes}

Ancorado na literatura supracitada, procedeu-se à análise das principais orientações dos visitantes com relação ao Congresso Nacional, nas amostras colhidas antes e depois da visita, como forma de observar possíveis mudanças trazidas pelo programa de visitação. Para tanto, escolheram-se três variáveis: a avaliação de desempenho, o que representaria influência no apoio específico; a confiança na Câmara dos Deputados, o que denotaria implicações para o apoio difuso, na perspectiva eastoniana; e

${ }^{25} 0,01$ level (2-tailed).

${ }^{26} N=382 ; X^{2}=16,534$; graus de liberdade: 8; ponto crítico: 15,5 para $5 \%$ e 20,1 para $1 \%$.

27 Excluindo a não resposta. 
a adesão à democracia (Questão 18), importante fator de uma cidadania crítica, e nesta chave, basilar para uma perspectiva positiva da reprovação ao desempenho.

O impacto no apoio específico se daria pela "boa impressão" passada pela visita, e seria reflexo de percepções momentâneas e não relacionadas à qualidade do sistema democrático, como a simpatia ou a antipatia do monitor, a beleza arquitetônica, o bom ou o mau atendimento (dimensão afetiva). Uma segunda dimensão, mais ligada à compreensão do conteúdo passado pela visita (dimensão cognitiva), estaria relacionada ao entendimento do papel da instituição para a democracia (dimensão avaliativa) e, desta forma, importaria em aumento do apoio difuso ao sistema político.

Os testes de associação entre as variáveis "desempenho qualificado", "confiança na Câmara dos Deputados qualificada" ou "adesão à democracia" e a "realização da visita" (amostras antes e depois da visita) não mostraram resultados significantes. Os valores do qui-quadrado tampouco permitiram refutar a hipótese de independência das variáveis. Pela amostra, portanto, não se pode afirmar com segurança que a participação na visita per se mude as orientações dos visitantes. A mudança ocorre, no entanto, se controlada pela escolaridade, principal "filtro" das percepções, de acordo com a literatura, como será mostrado a seguir.

\section{O Impacto da Visita sobre a Avaliação de Desempenho dos Parlamentares}

Em termos gerais, o programa impacta positivamente na melhoria da avaliação de desempenho dos parlamentares. Antes da visita, 57\% dos visitantes reprovavam o desempenho dos parlamentares, enquanto apenas 7,2\% aprovavam o trabalho dos seus representantes, e outros 30,8\% avaliavam 0 desempenho como regular. Após a visita, há um aumento de 3,7 pontos percentuais na avaliação positiva e uma redução de 12 pontos percentuais na avaliação negativa. A avaliação regular também subiu 7,6 pontos percentuais.

Como dito anteriormente, os testes não permitiram confirmar qualquer relação entre a avaliação de desempenho e a participação na visita. Quando controlado pela escolaridade, no entanto, o teste de qui-quadrado refuta a hipótese nula seguramente ${ }^{28}$. De forma diversa do observado no Quadro 2 - que mostra a diferença dentre as frequências observadas e esperadas na amostra como um todo (antes e depois da visita) - na amostra colhida antes da visita, a diferença da avaliação positiva entre os menos escolarizados é muito maior. Entre os que têm Ensino Fundamental, a aprovação é significantemente maior antes da visita $(6,4)$.

Quadro 5

Diferença entre frequência observada e frequência esperada para Avaliação de Desempenho Qualificada e Escolaridade antes da visita

\begin{tabular}{|l|c|c|c|c|}
\hline \multicolumn{5}{|c|}{ Avaliação de Desempenho Qualificada } \\
\hline \multicolumn{1}{|c|}{ Escolaridade } & Positiva & Regular & Negativa & Não sei \\
\hline Fundamental & 6,384615 & $-0,01538$ & $-0,70642$ & -1 \\
\hline Médio & 0,801126 & 0,224765 & $-0,26964$ & $-0,01538$ \\
\hline Superior & $-0,43195$ & $-0,05325$ & 0,08398 & 0,146269 \\
\hline Pós-Graduação & $-0,55913$ & $-0,07417$ & 0,130494 & $-0,8$ \\
\hline
\end{tabular}

${ }^{28} \mathrm{~N}=192 ; \mathrm{X}^{2}=27,28$; parâmetro $=21,666$; graus de liberdade $=9 ; \mathrm{p}=1 \%$. Excluindo a categoria não resposta. Não houve resposta "não sei" para escolaridade antes da visita em quaisquer categorias de avaliação de desempenho. 
HENRIQUE, A. L. O que pensa quem "bate à porta" de uma Casa que só "apanha"?...

Na amostra colhida após a visita, verifica-se uma queda substancial da diferença na avaliação positiva observada e esperada entre os com Ensino Fundamental, com relação à amostra colhida antes da visita (Quadro 6). A queda pode ser observada também, embora em menor grau, entre os com Ensino Médio. Há ainda um aumento da diferença da avaliação positiva observada e esperada entre os com Ensino Superior, embora em menor proporção. Observa-se também um aumento da avaliação regular entre os com Ensino Fundamental. Como já observado, a avaliação regular costuma tanto abrigar "indecisos", quanto pessoas que migraram de uma orientação extrema (positiva e negativa), mas que ainda não tomaram uma nova posição, ou que não querem tomá-la.

Quadro 6

Diferença entre frequência observada e frequência esperada entre Avaliação de Desempenho Qualificada e Escolaridade depois da visita

\begin{tabular}{|l|c|c|c|c|}
\hline \multicolumn{5}{|c|}{ Avaliação de Desempenho Qualificada } \\
\hline Escolaridade & Positiva & Regular & Negativa & Não sei \\
\hline Fundamental & 0,419118 & 0,855769 & $-0,73194$ & $\cdot 1$ \\
\hline Médio & 0,056088 & 0,323494 & $-0,30181$ & 0,122093 \\
\hline Superior & 0,188098 & $-0,16562$ & 0,072222 & 0,402616 \\
\hline Pós-graduação & $-0,38075$ & $-0,10023$ & 0,208687 & $-0,56136$ \\
\hline Não sei & -1 & -1 & 1,144444 & $\cdot 1$ \\
\hline
\end{tabular}

Entretanto, o valor do qui-quadrado $(14,419)$ não permite afirmar que esta queda seja relacionada à visita, já que não descarta a hipótese de independência das variáveis com a mesma segurança da amostra colhida antes da visita ${ }^{29}$. A queda, no entanto, é evidente, mesmo com relação à amostra como um todo, onde as variáveis estão relacionadas, o que, sem dúvida, denota um impacto da visita sobre as avaliações de desempenho dos parlamentares entre os visitantes, particularmente, os menos escolarizados.

Ao contrário do que ocorre com a observada mudança de opinião, o teste de qui-quadrado descarta a independência entre a declarada mudança de opinião e a avaliação de desempenho. Entre os que responderam após a visita e disseram ter mudado de opinião, a aprovação ao desempenho dos parlamentares é maior $(1,366)$.

Quadro 7

Diferença entre frequências observadas e esperadas para Avaliação de Desempenho Qualificada e Mudança de Opinião após a visita ${ }^{30}$

\begin{tabular}{|l|c|c|c|c|}
\hline \multicolumn{5}{|c|}{ Avaliação de Desempenho Qualificada } \\
\hline Mudança de opinião & Positiva & Regular & Negativa & Não sei \\
\hline Sim & 1,366738 & 0,048555 & $-0,31343$ & 0,204885 \\
\hline Não & $-0,59078$ & $-0,02099$ & 0,135484 & $-0,08856$ \\
\hline
\end{tabular}

A análise das respostas à pergunta aberta "Como?", no entanto, não corrobora a melhoria da avaliação após a visita. Em outras palavras, a mudança impacta no aumento da aprovação e na

${ }^{29}$ Retirou-se a não-resposta. $N=193 ; X^{2}=14,419$; graus de liberdade 12. Pontos críticos: 21,026 (5\%); 14,84 p =25\%, e 11,34 $\mathrm{p}=50 \%$

${ }^{30} \mathrm{~N}=222 ; \mathrm{X}^{2}=21,95$; grau de liberdade $=3$; ponto crítico: 11,$345 ; \mathrm{p}=1 \%$. Retirou-se a não-resposta. 
diminuição da reprovação ao desempenho parlamentar na amostra em geral, mas o visitante não identifica o que promoveu a melhoria da avaliação. Há ainda a possibilidade de o efeito resultar simplesmente do bom atendimento, gerando lip service.

Viu-se que a literatura associa o aumento da crítica às instituições democráticas ao aumento da escolaridade e da renda, com consequente mudança de valores (INGLEHART, 1988; 1999; 2003). Na análise dos índices de avaliação do trabalho parlamentar do Datafolha no período do mensalão, mencionada anteriormente, a escolaridade é mais importante do que a renda no que tange à mudança na avaliação de desempenho no período (HENRIQUE, 2011). A reação dos menos escolarizados frente a um escândalo conhecido por $84 \%$ dos brasileiros um mês após a primeira divulgação, de acordo com a pesquisa Datafolha, é mais lenta, e, provavelmente, dependente de mídias mais acessíveis.

Há, portanto, uma perspectiva alvissareira para o programa "Visite o Congresso" tanto enquanto ferramenta de melhoria da imagem institucional quanto de promoção de uma cultura cívica. Por um lado, após a visita, há um aumento da avaliação positiva do trabalho parlamentar na amostra em geral, preponderantemente com Ensino Superior, o que pode atestar a eficiência do programa enquanto ação de comunicação para a melhoria da percepção institucional. Por outro lado, os cidadãos menos escolarizados tornam-se mais críticos após a visita, o que pode significar uma melhoria nas dimensões cognitiva e avaliativa, refletida no aumento da insatisfação frente ao não atendimento de expectativas de desempenho dos parlamentares após a compreensão do papel deles esperado. Os monitores procuram divulgar os conteúdos de forma didática e acessível, além de permitir a interação entre o emissor e o receptor, para esclarecimento de dúvidas. Se resultante de maior avaliação de desempenho objetiva, a diminuição da aprovação pode importar em percepção de aumento da competência subjetiva dos "cidadãos crentes" (HeNRIQUE, 2011), na chave de Almond e Verba (1963), e, consequentemente, da cultura cívica e da participação.

Pelas possíveis consequências para a inclusão social e política dos menos escolarizados . 61,24\% do eleitorado têm até o Ensino Fundamental (TSE, 2010) ·, esta conclusão é particularmente importante para um programa de educação para a cidadania proposto pela "Casa de todos os brasileiros".

\section{O impacto da Visita sobre a Confiança no Congresso Nacional}

Da mesma forma que ocorreu com o desempenho, houve um aumento da confiança após a visita: de 23,5\% para 28,9\%. A desconfiança também diminuiu na amostra colhida após a participação no programa em 4,9 pontos percentuais (67,9\% e 63\%), mas, como dito anteriormente, a mudança não pôde ser atribuída ao impacto da visita per se.

A diferença também é mais visível entre os menos escolarizados, só que em menor proporção e em sentido contrário (Quadro 8). Depois da visita, a diferença entre a frequência observada e esperada de indivíduos que confiam na Câmara dos Deputados entre os com Ensino Fundamental é ligeiramente maior (0,92 para 1,49 antes da visita e após a visita, respectivamente). A segurança, no entanto, é menor (nível de significância 5\%) ${ }^{31}$, o que permite concluir que a visita aumenta a confiança entre os menos escolarizados, mas timidamente.

\footnotetext{
${ }^{31} \mathrm{~N}=193 ; \mathrm{X}^{2}=15,618 ;$ graus de liberdade $=8$ e parâmetro 15,507; $\mathrm{p}=5 \%$. Retirou-se a não-resposta.
} 
HENRIQUE, A. L. O que pensa quem "bate à porta" de uma Casa que só "apanha"?...

Quadro 8

Diferença entre frequências observadas e esperadas para Confiança na Câmara

dos Deputados Qualificada e Escolaridade após a visita

\begin{tabular}{|l|c|c|c|}
\hline \multicolumn{4}{|c|}{ Confiança na Câmara dos Deputados Qualificada } \\
\hline Escolaridade & Confiança Positiva & Confiança Negativa & Não sei \\
\hline Fundamental & 1,49569 & $-0,62597$ & -1 \\
\hline Médio & 0,160786 & $-0,02578$ & -1 \\
\hline Superior & $-0,11006$ & 0,009014 & 0,870155 \\
\hline Pós-Graduação & $-0,21348$ & 0,115292 & $-0,41515$ \\
\hline Não sei & 2,327586 & -1 & -1 \\
\hline
\end{tabular}

Estes achados também corroboram a literatura. A confiança é um valor que se desenvolve a partir de um relacionamento, que aumenta em proporção direta ao tempo, e que, ao contrário da maioria dos bens, não se esgota, mas aumenta com o uso (PUTNAM, 1993). É, por isso, um componente importante do apoio difuso ao sistema político (EASTON, 1965a; 1965b). Logo, a participação em uma breve visita não pode ter o mesmo impacto sobre a confiança institucional que tem sobre a avaliação de desempenho.

Similarmente, a análise do Quadro 9 permite observar que o aumento da confiança e a diminuição da desconfiança entre aqueles que disseram mudar de opinião ocorre, só que de forma bem mais tênue se comparada à avaliação de desempenho (Cf. Quadro 7).

\section{Quadro 9}

Diferença entre frequências observada e esperada para Confiança na Câmara dos Deputados e Declaração de Mudança de Opinião ${ }^{32}$

\begin{tabular}{|l|c|c|c|}
\hline \multicolumn{4}{|c|}{ Confiança na Câmara dos Deputados } \\
\hline Mudou de opinião & Confiança Positiva & Confiança Negativa & Não sei \\
\hline Sim & 0,390909 & $\cdot 0,15172$ & $\cdot 0,44192$ \\
\hline Não & $-0,16645$ & 0,064602 & 0,188172 \\
\hline
\end{tabular}

Para confirmar a "tímida" mudança de opinião, calculou-se a razão de chance entre os visitantes que confiam e os que desconfiam da Câmara dos Deputados antes (grupo um) e depois da visita (grupo dois). A razão de chance é calculada para comparar a probabilidade de algo acontecer em um grupo com a probabilidade de algo acontecer em outro grupo ${ }^{33}$.

A probabilidade de um visitante confiar na Câmara dos Deputados é maior depois da visita $(\mathrm{OR}=0,78)$. A probabilidade de um visitante desconfiar da Câmara dos Deputados é maior antes da visita $(\mathrm{OR}=1,42)$. Além disso, a probabilidade da dúvida, associada à resposta "não sei" também é maior depois da visita $(\mathrm{OR}=0,16)$. Estes resultados podem revelar o impacto da visita sobre um aumento da confiança na instituição, o que representa fator relevante, pelo aspecto difuso da confiança política.

$32 N=221: X^{2}=6,199$, graus de liberdade: 2 ; pontos críticos 5,99; $p=5 \%$. Retirou-se a não-resposta.

${ }^{33}$ Calculada a razão de chance (Odds Ratio, ou OR) entre os dois grupos, se obtivermos um valor igual a 1 significa que a probabilidade do evento acontecer em um grupo é igual a probabilidade de ela acontecer no outro. Se OR $<1$, significa que a probabilidade de o evento acontecer no segundo grupo é maior do que acontecer no primeiro grupo. Se OR $>1$, significa que a probabilidade de o evento acontecer no primeiro grupo é maior do que no segundo. 
OPINIÃO PÚBLICA, Campinas, vol. 19, n², novembro, 2013, p. 346-379

Tal repercussão pode ser confirmada pela possível mudança de opinião em outras variáveis fundamentais para o apoio difuso ao sistema político, como a adesão ao regime democrático.

O Impacto da Visita sobre a Adesão à Democracia

Neste survey, a adesão à democracia foi avaliada a partir de escolha única entre três opções sobre a forma de governo. A primeira, "A democracia é preferível a qualquer forma de governo", de acordo com a metodologia de Moisés (2010), estaria mais ligada a um comportamento "democrata"; a segunda, "Em algumas circunstâncias, um governo autoritário pode ser preferível à democracia", estaria mais próxima de uma orientação intermediária; e a terceira, "Tanto faz se o governo é democrático ou autoritário, o que importa é ter um bom governo para o povo", seria mais congruente com um comportamento autoritário.

A maioria dos entrevistados escolheu a opção mais democrática (59\%), mas 22\% dos visitantes escolheram a opção mais autoritária A opção intermediária foi a escolha de apenas 9,5\% dos entrevistados, mesmo percentual dos que não responderam.

De maneira geral, a preferência pela opção mais democrática cai na amostra após a visita $(61,1 \%$ pra $56,9 \%)$ e a opção mais autoritária aumenta de $17,6 \%$ para $26,5 \%$, o que, em termos de apoio difuso, não seria congruente com o aumento da confiança após a participação no programa. A literatura associa a adesão à democracia a uma maior confiança política. Os resultados podem derivar do comportamento ambivalente do brasileiro, ou seja, aquele que mistura traços de orientações democráticas e autoritárias, ainda comum entre os que viveram "lapsos importantes de suas vidas sob a influência de concepções autoritárias no tocante às suas instituições políticas" (MoısÉs, 2010, p.89). No Brasil, o contingente de ambivalentes chega a 54\%, contra 40\% na América Latina.

0 resultado do teste de qui-quadrado, no entanto, não permitiu confirmar evidência de relação entre nenhuma destas variáveis. Entretanto, o mesmo teste descartou com segurança a independência das variáveis adesão à democracia e escolaridade na amostra como um todo ${ }^{34}$. Os menos escolarizados tendem a preferir a opção mais autoritária (Quadro 10):

Quadro 10

Diferença entre frequências observadas e esperadas para Forma de Governo e Escolaridade na amostra em geral $^{35}$

\begin{tabular}{|l|c|c|c|}
\hline \multicolumn{4}{|c|}{ Forma de Governo } \\
\hline \multicolumn{1}{|c|}{ Escolaridade } & Democrático & Intermediáio & Autoritário \\
\hline Fundamental & $-0,3691$ & -1 & 1,451311 \\
\hline Médio & $-0,35939$ & 0,135628 & 0,939499 \\
\hline Superior & 0,015602 & 0,200257 & $-0,1288$ \\
\hline Pós-Graduação & 0,246964 & $-0,25564$ & $-0,57624$ \\
\hline Não sei & 0,51417 & -1 & -1 \\
\hline
\end{tabular}

${ }^{34} N=374 ; X^{2}=48,339 ;$ graus de liberdade = 8; ponto crítico $=20,09 ; p=1 \%$.

35 Retirou-se a não-resposta. 
HENRIQUE, A. L. O que pensa quem "bate à porta" de uma Casa que só "apanha"?...

Controlado pela escolaridade, pôde-se observar o impacto da visita sobre as orientações dos visitantes. Antes da visita (Quadro 11), é maior a frequência da opção autoritária entre os menos escolarizados, particularmente, os que têm Ensino Fundamental (2,854):

Quadro 11

Diferença entre frequências observada e esperada para Forma de Governo e Escolaridade antes da visita ${ }^{36}$

\begin{tabular}{|l|c|c|c|}
\hline \multicolumn{4}{|c|}{ Forma de Governo } \\
\hline \multicolumn{1}{|c|}{ Escolaridade } & Democrático & Intermediário & Autoritário \\
\hline Fundamental & $-0,63867$ & $\cdot 1$ & 2,854167 \\
\hline Médio & $-0,33594$ & 0,190476 & 1,083333 \\
\hline Superior & $-0,03036$ & 0,226643 & $-0,02426$ \\
\hline Pós-Graduação & 0,267428 & $-0,32234$ & $-0,76282$ \\
\hline
\end{tabular}

Conforme observado no Quadro 12, após a visita, é sensível a queda da diferença de frequência da preferência pela opção mais autoritária no mesmo segmento (de 2,854 para 0,783).

Quadro 12

Diferença entre frequências observada e esperada para Forma de Governo e Escolaridade depois da visita ${ }^{37}$

\begin{tabular}{|l|c|c|c|}
\hline \multicolumn{4}{|c|}{ Forma de Governo } \\
\hline \multicolumn{1}{|c|}{ Escolaridade } & Democrático & Intermediário & Autoritário \\
\hline Fundamental & $-0,20588$ & -1 & 0,783019 \\
\hline Médio & $-0,3802$ & 0,084648 & 0,826507 \\
\hline Superior & 0,065052 & 0,177163 & $\cdot 0,20289$ \\
\hline Pós-Graduação & 0,205882 & $-0,17647$ & $-0,40566$ \\
\hline Não sei & 0,588235 & -1 & -1 \\
\hline
\end{tabular}

Embora a comparação das amostras antes e depois da visita aponte um aumento da opção mais autoritária após a participação no programa, quando controlado pela escolaridade, observa-se um impacto positivo da visita sobre a diminuição desta preferência entre os menos escolarizados, nesta amostra.

\section{Conclusão}

O survey realizado entre os visitantes do Congresso Nacional confirma uma série de achados da literatura. Mesmo entre os cidadãos que o procuram em suas horas de lazer, os índices de reprovação ao trabalho parlamentar e de desconfiança com relação à instituição são compatíveis com a literatura em uma amostra mais escolarizada. Nesta amostra, a avaliação de desempenho também está relacionada à confiança em todas as Casas do Congresso Nacional.

A análise das orientações coletadas em amostras antes e depois da visita permite afirmar que o contato com a instituição (dimensão afetiva) e a informação prestada durante a visita (dimensão

${ }^{36} \mathrm{~N}=185 ; \mathrm{X}^{2}=31,279$; graus de liberdade $=6$; ponto crítico: 16,$8 ; \mathrm{p}=1 \%$. Retirou-se a não-resposta.

${ }^{37} \mathrm{~N}=189 ; \mathrm{X}^{2}=20,041$; graus de liberdade=8; ponto crítico= 20,09; $\mathrm{p}=1 \%$ e ponto crítico $15,5 \%$ a $5 \%$. Retirou-se a não-resposta. 
cognitiva) acabam por modificar a percepção da instituição e de seus atores (dimensão avaliativa). As variáveis, no entanto, só estão relacionadas quando controladas pela escolaridade, fator determinante para a percepção da confiança na Câmara dos Deputados, para a avaliação de desempenho e para a adesão à democracia (na amostra e na literatura).

O impacto da visita é maior sobre a avaliação de desempenho dos parlamentares, o que, na perspectiva eastoniana, pode importar em aumento do apoio específico. A aprovação é maior na amostra coletada após a visita - o que pode atestar a eficácia do programa de visitação como ferramenta para a melhoria da imagem institucional. A mudança de opinião e a avaliação de desempenho estão relacionadas. Há maior aprovação entre aqueles que declaram ter mudado de opinião após participar do programa em relação à hipótese de independência das variáveis.

Por outro lado, há uma sensível diminuição da diferença entre as frequências esperada e observada da aprovação ao desempenho dos parlamentares entre os segmentos menos escolarizados, minoritários na amostra, particularmente os com Ensino Fundamental, após a participação no programa. Os menos escolarizados são os que mais aprovam o desempenho parlamentar na amostra e na literatura. Esta mudança poderia representar um aumento da capacidade de avaliação indutiva do papel esperado dos representantes entre os menos escolarizados, que, possivelmente pelo menor acesso à informação e à instituição, tornam-se mais suscetíveis aos conteúdos, expostos de maneira didática e concreta.

Já com relação à confiança na Câmara dos Deputados, observa-se pequeno aumento após a visita na amostra como um todo. Quando controlado pela escolaridade, o aumento também é maior entre os com Ensino Fundamental. O menor impacto é previsível. Ao contrário da avaliação específica do desempenho - que pode decorrer simplesmente do bom ou do mau atendimento -, a confiança constróise a partir da reciprocidade ao longo do tempo, como afirma a própria literatura. Ainda assim, as chances de um visitante confiar na Câmara dos Deputados após a visita são maiores do que antes de participar do programa.

Os resultados tornam-se mais relevantes quando acompanhados de diminuição de orientações autoritárias e/ou de aumento da adesão à democracia - valor central do apoio difuso ao sistema político, na perspectiva eastoniana. A frequência da opção mais autoritária - representada pela resposta: "Tanto faz se o governo é democrático ou autoritário, o que importa é ter um bom governo para o povo", diminui sensivelmente em relação à hipótese nula entre os com Ensino Fundamental, após a visita, embora a tendência não seja observada na amostra como um todo.

Estes achados, embora modestos, são importantes para o programa de visitas enquanto instrumento de educomunicação e de melhoria da qualidade do regime, pela construção de uma cultura cívica, na perspectiva de Almond e Verba. As conclusões mostram que a visita pode aumentar a cidadania crítica, especialmente no segmento onde ela é mais necessária: os segmentos menos escolarizados e com menor renda.

Em termos de Brasil, o impacto é ainda maior. Embora o segmento com Ensino Fundamental seja o menos presente na amostra, ele é o mais numeroso entre a população brasileira e entre os eleitores. Além disso, a baixa escolaridade está associada à baixa renda na amostra e na literatura. 
HENRIQUE, A. L. O que pensa quem "bate à porta" de uma Casa que só "apanha"?...

Os achados abrem, portanto, nova perspectiva para a pesquisa na Ciência Política: os programas de visitação do Legislativo como ferramentas de educação para a democracia, e, por esta via, de promoção da melhoria da qualidade do regime, inclusive porque, embora o trabalho e as atitudes dos parlamentares dentro e fora da instituição ainda sejam o principal parâmetro para a avaliação do desempenho do Congresso Nacional, as ações institucionais também contam para $19 \%$ dos visitantes.

A crítica, o debate e a pesquisa são, portanto, muito bem-vindos. Para tanto, o banco de dados deste survey será disponibilizado no Consórcio de Informações Sociais (CIS) ${ }^{38}$.

\section{Referências Bibliográficas}

Almeida, A. C.; Schroeder, A.; Cheibub, Z. (Orgs.). PESB: Pesquisa Social Brasileira, 2002 (Banco de dados). Rio de Janeiro: Universidade Federal Fluminense (UFF). Disponível: Consórcio de Informações Sociais, 2004. Disponível em: <http://www.cis.org.br>. Acesso em: 27 mar. 2010.

Almond, G; Verba, S. The Civic Culture: Political Attitudes and Democracy in Five Nations. $3^{a}$ ed. Newbury Park: Sage, 1963.

DAHL, R. A. Poliarquia: Participação e Oposição. São Paulo: Editora Universidade de São Paulo, 1997.

“A Democratic Paradox?". Political Science Quarterly, New York, vol. 115, n 1, p. 35-40, nov. 2000.

DALTON, R. Democratic Challenges: The Erosion of political Support in Advanced Industrial Democracies. Oxford: Oxford University Press, 2004.

DELla PortA, D. Social capital, beliefs in government, and political corruption. In: PhARR, S.; PUTNAM, R. D.

(Eds.). Disaffected democracies: what's troubling the trilateral countries? Princeton: Princeton University Press,

p. $202 \cdot 228,2000$

Diamond, L.; Morlino, L. (Orgs.). Assessing the Quality of Democracy. Baltimore: The John Hopkins University Press, 2005.

EASTON, D. Framework for Political Analyses. Englewood Cliffs: Prentice-Hall, 1965a.

A System Analysis of Political Life. New York: John Wiley and Sons, Inc., 1965b.

Giddens, A. The Consequences of Modernity. Stanford: Stanford University Press, 1990.

Harrison, L. E.; Huntington, S. P. A Cultura Importa. Rio de Janeiro: Record, 2000.

Henrique, A. L. "Cidadãos Crentes, Críticos e Ocultos: as várias faces da cidadania brasileira em sua relação com a confiança e as instituições democráticas na Nova República." [Online] Brasília. Dissertação (Mestrado em Ciência Política) - Instituto Universitário de Pesquisas do Rio de Janeiro - luperj, 2009. Disponível em:

<http://bd.camara.gov.br/bd/handle/bdcamara/3635>. Acesso em: 10 ago. 2013.

"Confiança e democracia: aspectos de uma instável relação estável". E-Legis - Revista Eletrônica do Programa de Pós-Graduação da Câmara dos Deputados, Brasília, 4, jun. 2010a. Disponível em: <http://inseer.ibict.br/e. legis/index.php/e-legis/article/view/37>. Acesso em: 01 jul. 2010.

Cidadãos Crentes, Críticos e Ocultos: Assimetrias da Confiança no Congresso Nacional. [Online] Trabalho apresentado no $7^{\circ}$ Encontro ABCP. 2010b. Disponível em:

<http://cienciapolitica.servicos.ws/abcp2010/arquivos/12_7_2010_11_26_57.pdf> Acesso em: 15 nov. 2011.

A Metonímia do Legislativo: aspectos da confiança no Congresso Nacional enquanto sistema perito. [Online] $\overline{\text { Trabalho }}$ apresentado na $34^{\circ}$ Conferência Anual da Anpocs. 2010c. Disponível em:

<http://www.anpocs.org.br/portal/index.php?option=com_wrapper\&ltemid=90> Acesso em: 15 nov. 2011.

38 Disponível em:< http://www.nadd.prp.usp.br/cis/> 
. Quando Imagem vira Caso de Democracia: Aspectos da Desconfiança no Congresso Nacional Brasileiro. In: Nicolau, J; Braga, R. (Orgs.). Para Além das Urnas: reflexões sobre a Câmara dos Deputados. Brasília: Centro de Documentação e Informação. Edições Câmara, p. 417.452, 2011.

HoEl, P. Estatística Elementar. São Paulo: Editora Atlas S.A, 1989.

Honneth, A. Redistribution as Recognition: A Response to Nancy Fraser. In: Fraser, N.; Honneth, A. (orgs.). Redistribution or recognition? Invisibility: on the Epistemology of Recognition, A Philosophical Exchange. London: Verso, 2001.

Huntington, S. P. The Third Wave: Democratization in the Late 20th Century. Norman: University of Oklahoma Press, 1991

INGLEHART, R. "The Renaissance of Political Culture". American Political Science Review, vol. 82, n 4, p. 1203-1230, 1988.

Trust, Well-Being and Democracy. In: WARREN, M. (Ed.). Democracy and Trust. Cambridge: Cambridge University Press, p. 88-120, 1999.

How solid is mass support for democracy - and how can we measure it?. 2003. Disponível em: <http://www.asianbarometer.org/newenglish/publications/ConferencePapers/2003conference/T_03_no.11.pdf>Acesso em: 15 nov. 2011

LAGos, M. "Between Stability and Crisis in Latin America". Journal of Democracy, vol. 12, n 1, p. 135.145, 2001.

LinZ, J.; StePAn, A. "Toward consolidated democracies". Journal of Democracy, p. 14-16, 1996

LIJPhART, A. Modelos de Democracia. Rio de Janeiro: Editora Civilização Brasileira, 2003.

Lummann, N. Familiarity, Confidence, Trust: Problems and Alternatives. In: GambeTTA, D. (Ed.). Trust: Making and Breaking Cooperative Relations, electronic edition. Department of Sociology, University of Oxford, chapter 6, p. 94-107, 2000. <http://www.sociology.ox.ac.uk/papers/luhmann94-107.pdf>

Meneguello, R. A Democracia Brasileira, 21 anos depois. In: Primer Congreso Latinoamericano de Opinión Publica. "Opinión Pública, conflicto social y orden político". Uruguai: abr. 12·14, 2007. Anais... Disponível em:

<http://www.waporcolonia.com/presentaciones.html>. Acesso em: 15 nov. 2008.

Aspectos do Desempenho Democrático: Estudo sobre a Adesão à Democracia e Avaliação do Regime. In: Moısés, J. Á. (Ed.). Democracia e Confiança. São Paulo: Edusp, p. 123.148, 2010.

MerkEL, W. "Embedded and Defective Democracies". Democratization, vol. 11, n 5, p. 33-58, 2004

Moısés, J. A. (Org.). Democracia e Confiança: por que os cidadãos desconfiam das instituições públicas? São Paulo: Editora da Universidade de São Paulo, 2010

NORRIS, P. Introduction: the growth of critical citizens? In: (Ed.). Critical citizens: global support for democratic government. New York: Oxford University Press, p. 1-27, 1999

. Critical citizens: global support for democratic government. Oxford: Oxford University Press, 1999.

Democratic Deficit: Critical Citizens Revisited. Cambridge: Cambridge University Press, 2011.

Making Democracy Governance Work. Cambridge: Cambridge University Press, 2012.

Offe, C. How can we trust our fellow citizens? In: WaRREN, M. (Ed.). Democracy \& Trust. Cambridge: Cambridge University Press, p. 42.87, 1999.

PHARR, S. Officials' misconduct and public distrust: Japan and the trilateral democracies. In: PutnAm, R. (ed.). Disaffected democracies: what's troubling the trilateral countries? Princeton: Princeton University Press, 2000.

Peruzzotti, E.; Smulovitz. C. Social Accountability: An Introduction [online]. University of Pittsburgh Press. 2006. Disponível em: <http://www.upress.pitt.edu/htmISourceFiles/pdfs/9780822958963exr.pdf.> Acesso em: 15 nov. 2011.

PITKIN, H. F. The Concept of Representation. London: University of California Press, Ltd., 1967.

PORTO, M. A crise de confiança política e suas instituições. In: BAQUERO, M. (Org.). Condicionantes da consolidação democrática: ética, mídia e cultura política. Porto Alegre: Editora da Universidade Federal do Rio Grande do Sul, 1996. 


\section{HENRIQUE, A. L. O que pensa quem "bate à porta" de uma Casa que só "apanha"?...}

Powell, G. B. The Chain of Responsiviness. In: DiAmond, L.; MorLINo, L. (Orgs.). Assessing the Quality of Democracy. Baltimore: The John Hopkins University Press, 2005.

Power, T. J.; Jamison, G. “Desconfiança política na América Latina”. Opinião Pública, vol. XI, n¹, p. 64-93, 2005.

PUHLE, H. J. Democratic Consolidation and "Defective Democracies". In: Conferencia Impartida Universidad Autonoma de Madrid, Anais.... Madrid, p. 1-20, 2005.

Putnam, R. Making Democracy Work: Civic Traditions in Modern Italy. Princeton, New Jersey, USA: Princeton University Press, 1993.

"Bowling Alone: America's Declining Social Capital”. Journal of Democracy, vol. 6, n 1, p. 65-78, 1995.

2000.

Bowling Alone: The Collapse and Revival of American Community. New York: Simon \& Schuster Paperbacks,

\section{Apêndices}

\section{Apêndice 1}

\section{Questionário para usuários do Programa de Visitação}

Prezado visitante, ${ }^{39}$

Este questionário faz parte de uma pesquisa universitária e pretende conhecer a opinião dos visitantes da Casa quanto a diversos aspectos da vida política. Ele se divide em duas partes: a primeira é apresentada antes do início da visita e a segunda logo depois do passeio pela Casa ter se encerrado.

Não é necessário se identificar. Caso queira, você pode deixar seu contato, a fim de receber, ao final da pesquisa, os relatórios obtidos. Em nenhum momento a identificação do respondente será utilizada para outro fim que não seja o de envio autorizado do relatório da pesquisa.

Muito obrigado(a) por sua participação.

\section{Informações preliminares}

1. Dia da Visita:

2. Horário:

3. Guia:

\section{ANTES da Visita}

4. Você sabe como se chama o local onde você está?40

( ) Câmara ( ) Senado ( ) Congresso Nacional

( ) Outra:

5. Qual é o motivo da sua visita?

( ) Turismo ( ) Conhecer os representantes ou outra motivação cívica

( ) Curiosidade ( ) Necessidade (água, descanso, banheiros, fugir do sol e do calor)

( ) Outra:

6. O que é o Congresso Nacional?

7. Qual é a finalidade da/Para que serve a Câmara dos Deputados?

( ) Fazer leis ( ) Fiscalizar os outros Poderes ( ) Representar os eleitores

( ) Outra:

8. Quem trabalha na Câmara?

( ) Deputados ( ) Senadores ( ) Presidente da República

( ) Outra:

9. O que você espera do trabalho dos deputados?

10. Qual é a finalidade do/Para que serve o Senado?

( ) Fazer leis ( ) Fiscalizar os outros Poderes ( ) Representar os eleitores

( ) Outra:

${ }^{39} \mathrm{O}$ entrevistador informa ao entrevistado sobre estas condições. Preferencialmente, o texto pode ser lido ou entregue de forma impressa, a fim de uniformizar o entendimento. O público consiste de potenciais eleitores (acima de 16 anos e até 70 anos). As respostas são únicas para cada questão e espontâneas (não induzidas).

40 Para todas as questões que se seguem, as opções não são fornecidas, apenas assinaladas pelo entrevistador. 
11. Quem trabalha no Senado?

( ) Deputados ( ) Senadores ( ) Presidente da República ( ) Outra:

12. E o que você espera do trabalho dos senadores?

13. O que faz um deputado?

14. O que faz um senador?

15. Você acha que os deputados e senadores que estão no Congresso hoje estão tendo um desempenho:

( ) Ótimo ( ) Bom ( ) Regular ( ) Ruim ( ) Péssimo

16. Você acha que os deputados que estão no Congresso hoje estão tendo um desempenho:

( ) Ótimo ( ) Bom ( ) Regular ( ) Ruim ( ) Péssimo

17. Você acha que os senadores que estão no Congresso hoje estão tendo um desempenho:

( ) Ótimo ( ) Bom ( ) Regular ( ) Ruim ( ) Péssimo

Vou citar algumas instituições e gostaria de saber qual é o grau de confiança que você tem em cada um delas:

18. Câmara dos Deputados

( ) Muita confiança ( ) Alguma confiança ( ) Pouca Confiança

( ) Nenhuma Confiança

19. Senado Federal?

( ) Muita confiança ( ) Alguma confiança ( ) Pouca Confiança

( ) Nenhuma Confiança

20. Congresso Nacional?

( ) Muita confiança ( ) Alguma confiança （）Pouca Confiança

( ) Nenhuma Confiança

21. E quanto aos deputados federais?

( ) Muita confiança ( ) Alguma confiança ( ) Pouca Confiança

( ) Nenhuma Confiança

22. E quanto aos senadores?

( ) Muita confiança ( ) Alguma confiança ( ) Pouca Confiança

( ) Nenhuma Confiança

23. Você se lembra em quem votou para deputado federal na última eleição (2006)?

( ) $\operatorname{Sim}$ ( ) Não

24. Você se lembra em quem votou para senador na última eleição (2006)?

( ) $\operatorname{Sim}$ ( ) Não

25. Você poder dizer o nome de algum deputado federal em exercício?

( ) Sim:

Vc sabe a que partido pertence? ( ) Sim ( ) Não

( ) Não

26. Você poder dizer o nome de algum senador em exercício?

( ) $\mathrm{Sim}:$

Vc sabe a que partido pertence? () Sim () Não

( ) Não

27. Diga a primeira palavra ou nome que vem à sua cabeça quando eu falo em:

Governo

Congresso Nacional

Câmara dos Deputados

Senado Federal

Deputado Federal

Senador

Democracia

28. Sua opinião sobre o Congresso Nacional é formada basicamente por qual fonte?

( ) Imprensa ( ) Familiares ( ) Amigos ( ) Escola

( ) Ambiente de trabalho

Outra:

29. As notícias sobre política veiculadas pela imprensa representam suas dúvidas e/ou opiniões?

( ) Não representam ( ) Representam pouco ( ) Representam

( ) Representam muito

30. Em sua opinião, a imprensa traz as questões mais importantes sobre política nacional?

( ) $\operatorname{Sim}($ ) Não

31. Em sua opinião, qual é a função da imprensa?

32. Você se sente suficientemente informado(a) pela imprensa sobre os trabalhos do Congresso Nacional?

( ) Não ( ) Pouco informado(a) ( ) Informado(a) ( ) Muito informado(a)

33. Você usa outro meio para se informar sobre os trabalhos do Congresso que não seja qualquer material de imprensa (jornais e revistas, TV ou rádio)?

( ) $\operatorname{Sim}$ ( ) Não

34. Você pode dizer seu nome para a segunda parte do questionário, logo depois da visita?

Nome:

35. Você quer deixar um contato (preferencialmente e-mail / endereço de correio eletrônico)? 
HENRIQUE, A. L. O que pensa quem "bate à porta" de uma Casa que só "apanha"?...

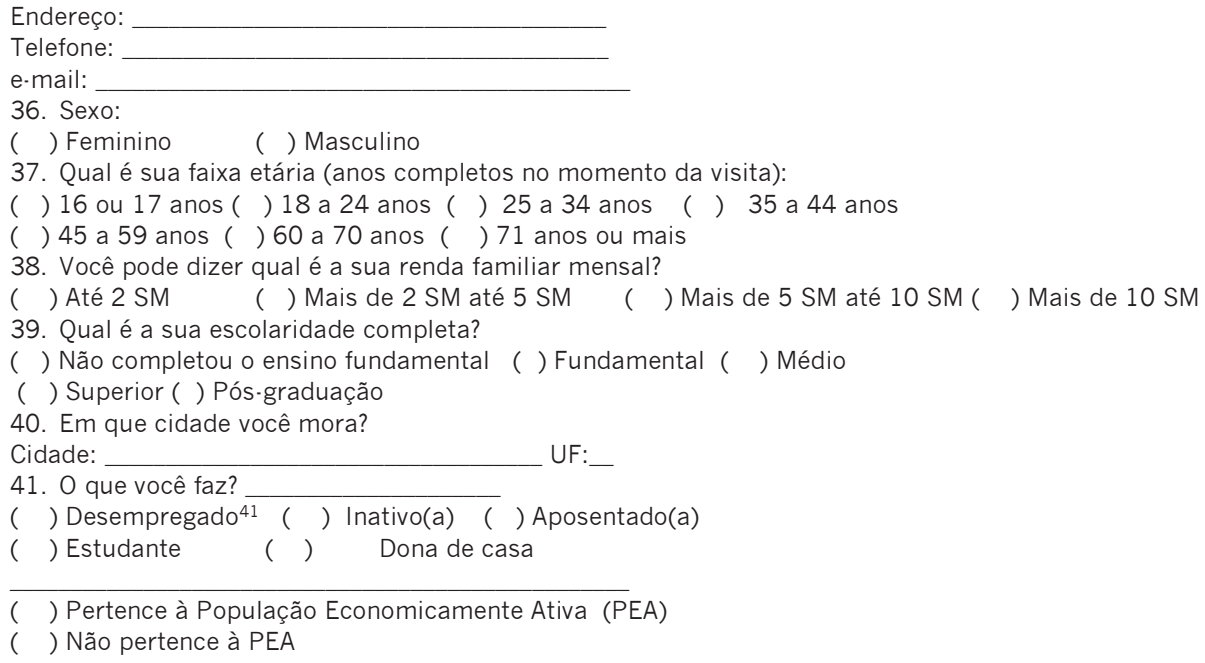

1. O que você mais gostou na visita?

2. O que você menos gostou na visita?

3. Você aprendeu alguma coisa sobre a Câmara, o Senado Federal e/ou o Congresso Nacional que não sabia antes da visita?

( ) Não

( ) Sim

4. Como você responde agora à pergunta "para que serve a Câmara"?

( ) Fazer leis ( ) Fiscalizar os outros Poderes ( ) Representar os eleitores

( ) Outra:

5. Como você responde agora à pergunta "para que serve o Senado"?

( ) Fazer leis ( ) Fiscalizar os outros Poderes ( ) Representar os eleitores

( ) Outra:

6. Você acha que os deputados que estão no Congresso hoje estão tendo um desempenho:
( ) Ótimo
( ) Bom ( ) Regular
( ) Ruim
( ) Péssimo

7. Caso tenha mudado a opinião, qual o motivo da mudança?

8. Você acha que os senadores que estão no Congresso hoje estão tendo um desempenho:
( ) Ótimo
( ) Bom ( ) Regular
( ) Ruim
( ) Péssimo

9. Caso tenha mudado a opinião, qual o motivo da mudança?

10. E agora, qual o grau de confiança que você tem na Câmara dos Deputados?

( ) Muita confiança ( ) Alguma confiança ( ) Pouca Confiança

( ) Nenhuma Confiança

11. Caso tenha mudado a opinião, qual o motivo da mudança?

12. E no Senado Federal?

( ) Muita confiança ( ) Alguma confiança ( ) Pouca Confiança

( ) Nenhuma Confiança

13. Caso tenha mudado a opinião, qual o motivo da mudança?

Muito obrigado (a) por sua participação.

\footnotetext{
41 Tem procurado emprego no período da pesquisa (um ano)? Se não, é inativo, ou seja, não pertence à PEA.
} 


\section{Apêndice 2 \\ Questionário para usuários \\ do Programa de Visitação}

Prezado visitante,

Este questionário faz parte de uma pesquisa universitária e pretende conhecer a opinião dos visitantes da Casa quanto a diversos aspectos da vida política. Não é necessário se identificar. Ao final, pedimos que o questionário seja depositado na urna identificada, ou que seja entregue a um de nossos atendentes. Muito obrigado por sua participação. Ela é muito importante!

\section{Informações preliminares}

1. Data da Visita:_ / _ /

Dia da semana:__ Horário:

2. Você está respondendo? ( ) antes da visita ( ) depois da visita

3. Qual é o motivo da sua visita? ( ) Turismo ( ) Conhecer os parlamentares

( ) Motivação cívica ( ) Curiosidade ( ) Compromisso no Congresso

( ) Para tomar água, descansar, banheiros, fugir do sol e do calor

( ) Outro:

4. Você já participou da visita ao Congresso Nacional antes de hoje?

( ) Sim Quantas vezes?___ ( ) Não

5. Qual é a finalidade da/Para que serve o Congresso Nacional?

( ) Fazer leis/aprovar projetos ( ) Fiscalizar os outros Poderes ( ) Representar eleitores/cidadãos

( ) Debater temas de interesse da nação

( ) Governar ( ) Ajudar os necessitados ( ) Não sei

6. Em sua opinião, são obrigações dos deputados e senadores:

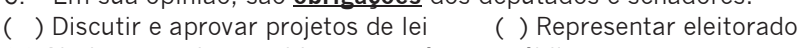

( ) Ajudar a resolver problemas em órgãos públicos

( ) Dar dinheiro/ajudar pessoas necessitadas ( ) Fazer obras em seu estado

( ) Ajudar seus eleitores a conseguir um emprego

( ) Outra ( ) Não sei

7. Você acha que os deputados e senadores que estão atualmente no Congresso estão tendo um desempenho:
( ) Ótimo
( ) Bom ( ) Regular
( ) Ruim
( ) Péssimo ( ) Não sei

8. Como você avalia o desempenho do Congresso Nacional?

( ) Pelo trabalho dos deputados e senadores

( ) Pelas atitudes dos deputados e senadores, mesmo que fora do Congresso Nacional

( ) Pelas ações da Instituição ( ) Não sei

9. Sua opinião sobre o Congresso Nacional é formada principalmente por qual fonte?

( ) Jornais ( ) Revista ( ) TV ( ) Familiares ( ) Amigos

( ) Instituição de ensino ( ) Ambiente de trabalho Não sei

10. As notícias sobre política veiculadas pela imprensa representam suas dúvidas e/ou opiniões?

( ) Sim, representam pouco ( ) Sim, representam

( ) Sim, representam muito ( ) Não representam ( ) Não sei

11. Em sua opinião, a imprensa traz as questões mais importantes sobre política nacional?
( ) Sim
( ) Não
( ) Não sei

12. Você se sente suficientemente informado(a) pela imprensa sobre os trabalhos do Congresso Nacional?

Sim: ( ) Pouco informado(a) ( ) Sim, Informado(a) ( ) Muito informado(a)

( ) Não Informado (a) ( ) Não sei

13. Em sua opinião, qual é a função da imprensa? ( ) Informar ( ) Denunciar

( ) Ajudar na tomada de decisões ( ) Outra:

( ) Não sei

Vou citar algumas instituições e gostaria de saber qual é o grau de confiança que você tem em cada uma delas:

14. Câmara dos Deputados?

( ) Muita confiança ( ) Alguma confiança

( ) Pouca Confiança

( ) Nenhuma Confiança ( ) Não sei

15. Senado Federal?

( ) Muita confiança ( ) Alguma confiança

( ) Pouca Confiança

( ) Nenhuma Confiança ( ) Não sei

16. Congresso Nacional?

( ) Muita confiança ( ) Alguma confiança

( ) Pouca Confiança

( ) Nenhuma Confiança ( ) Não sei 
HENRIQUE, A. L. O que pensa quem "bate à porta" de uma Casa que só "apanha"?...

17. Com qual das seguintes frases você está mais de acordo:

( ) A democracia é preferível a qualquer forma de governo

( ) Em algumas circunstâncias, um governo autoritário pode ser preferível à democracia

( ) Tanto faz se o governo é democrático ou autoritário, o que importa é ter um bom governo para o povo.

18. Com qual das seguintes frases você está mais de acordo:

( ) O Congresso Nacional é fundamental para a democracia

( ) Em algumas circunstâncias, o Congresso pode ser fechado.

( ) Podemos viver sem o Congresso Nacional. O que importa é ter um bom governo para o povo.

19. Você se lembra em quem votou para deputado federal em 2006 ?

( ) Sim ( ) Não ( ) Não votou (facultativo) ( ) Não votou (pular para pergunta 21)

20. Lembra o partido do candidato?

( ) Sim Qual ( ) Não

21. Você se lembra em quem votou para senador na última eleição (2006)? ( ) Sim （ ) Não ( ) Não votou

(facultativo) ( ) Não votou (pular para pergunta 23)

22. Lembra o partido?

( ) Sim Qual_ ( ) Não

23. Você poder dizer o nome de algum deputado federal em exercício?

( ) Sim Cite:

( ) Não

24. Você poder dizer o nome de algum senador em exercício?

( ) Sim. Cite: ( ) Não

\section{Dados Pessoais:}

25. Sexo: ( ) Feminino ( ) Masculino

26. Quantos anos você tem (completos no momento da visita):

( ) 16 ou 17 anos ( ) 18 a 24 anos ( ) 25 a 34 anos

( ) 35 a 44 anos ( ) 45 a 59 anos ( ) 60 anos ou mais

27. Você pode dizer qual é a sua renda familiar mensal?

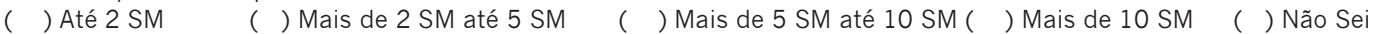

28. Qual é seu grau de escolaridade, mesmo que incompleta?

( ) Fundamental ( ) Médio ( ) Superior ( ) Pós-graduação ( ) Não sei

29. Em que cidade você mora? Cidade: UF:

30. O que você faz (ocupação principal)?

( ) Desempregado Há quanto tempo?

Se já fez a visita, responda:

31. O que você mais gostou da visita:

( ) Plenário Câmara ( ) Plenário Senado ( ) Salão Verde

( ) Túnel do Tempo ( ) Nada ( ) Não sei

32. O que você menos gostou da visita:

33. Você aprendeu alguma coisa sobre a Câmara, ou sobre o Senado Federal e/ou o Congresso Nacional que não sabia antes da visita?

( ) Não ( ) Sim O quê?

34. Sua opinião sobre o Congresso mudou após a visita? ～） Não ( ) Sim Como?

Ana Lúcia Henrique - analuhenrique@gmail.com

Submetido à publicação em dezembro de 2011.

Versão final aprovada em julho de 2013. 